\title{
A Condensed Introduction to the Doubly Fed Induction Generator Wind Energy Conversion Systems
}

\author{
Julius Mwaniki, ${ }^{1}$ Hui Lin, ${ }^{1}$ and Zhiyong Dai \\ ${ }^{1}$ Department of Electrical Engineering, School of Automation, Northwestern Polytechnical University, Xi'an 710129, China \\ ${ }^{2}$ Automatic Control Department, School of Mechano-Electronic Engineering, Xidian University, Xian 710071, China \\ Correspondence should be addressed to Julius Mwaniki; jukamwa@gmail.com
}

Received 10 March 2017; Revised 9 May 2017; Accepted 23 May 2017; Published 22 June 2017

Academic Editor: Yuh-Shyan Hwang

Copyright (c) 2017 Julius Mwaniki et al. This is an open access article distributed under the Creative Commons Attribution License, which permits unrestricted use, distribution, and reproduction in any medium, provided the original work is properly cited.

\begin{abstract}
The increase in wind power penetration, at $456 \mathrm{GW}$ as of June 2016, has resulted in more stringent grid codes which specify that the wind energy conversion systems (WECS) must remain connected to the system during and after a grid fault and, furthermore, must offer grid support by providing reactive currents. The doubly fed induction generator (DFIG) WECS is a well-proven technology, having been in use in wind power generation for many years and having a large world market share due to its many merits. Newer technologies such as the direct drive gearless permanent magnet synchronous generator have come up to challenge its market share, but the large number of installed machines ensures that it remains of interest in the wind industry. This paper presents a concise introduction of the DFIG WECS covering its construction, operation, merits, demerits, modelling, control types, levels and strategies, faults and their proposed solutions, and, finally, simulation. Qualities for the optimal control strategy are then proposed. The paper is intended to cover major issues related to the DFIG WECS that are a must for an overview of the system and hence serve as an introduction especially for new entrants into this area of study.
\end{abstract}

\section{Introduction}

Wind power was expected to supply $5 \%$ of electrical power worldwide when it hit $500 \mathrm{GW}$ at the end of 2016 up from $456 \mathrm{GW}$ at end of June 2016. By the end of 2020, the total installed capacity is projected to be $1900 \mathrm{GW}$ [1]. Among the applied wind energy conversion systems (WECS) configurations, the four most common ones are designated types A to D. Type A utilizes a fixed speed turbine connected to a squirrel cage induction generator (SCIG) through a gearbox. Type $B$ is a variable speed turbine connected through a gearbox to a wound rotor induction generator (WRIG) whose rotor is connected to a variable resistance. Both types A and B utilize a soft starter to smoothen connection to the grid during startup operations and a capacitor bank for reactive power supply. Type $C$ is also a variable speed turbine connected through a gearbox to a WRIG. However, the rotor output is fed to the grid through a partially rated frequency converter. This is also referred to as the doubly fed induction generator (DFIG). Type D involves a variable speed turbine connected either directly or through a gearbox to a WRIG, a wound rotor synchronous generator (WRSG), or a permanent magnet synchronous generator (PMSG) which connects to the grid through a fully rated frequency converter. The gearless type D WECS are direct driven large diameter multipole generators. Their large size and associated weight, in addition to the higher cost of the fully rated converter, erode the advantage of reduced cost and maintenance afforded by eliminating the gearbox [2]. The merits of the DFIG make it one of the most widely used generators for WECS. The DFIG WECS have been in use in wind power generation for many years now and have a large share of the world market. Whereas newer technologies such as the direct drive gearless PMSG have come up to challenge its market share, the large number of installed machines ensures that it remains of interest in the wind industry.

The DFIG WECS is a mix of aerodynamic, mechanical, electromagnetic, and electronic systems, and as such, control of the various subsystems in both steady and transient states is quite complex, especially since the increase in wind power penetration has resulted in more stringent grid codes which 


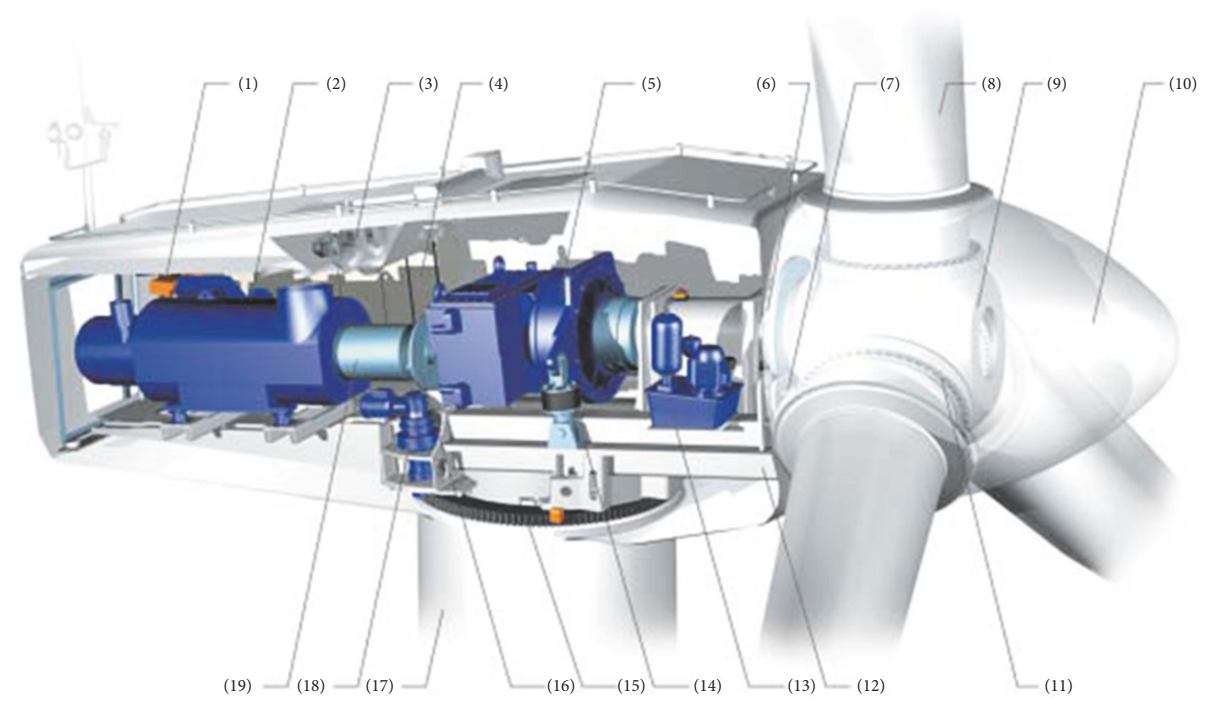

Figure 1: Components of a wind turbine [5]. (1) Service crane. (2) Generator. (3) Cooling system. (4) Top control unit. (5) Gearbox. (6) Main shaft with two bearings. (7) Rotor lock system. (8) Blade. (9) Hub. (10) Hub cover. (11) Blade bearing. (12) Bed frame. (13) Hydraulic unit. (14) Shock absorbers. (15) Yaw ring. (16) Brake. (17) Tower. (18) Yaw gears. (19) Transmission high speed shaft.

specify that the WECS must remain connected to the system even when a fault occurs and, furthermore, must provide reactive currents to support the grid voltages. This is made more difficult by the intermittent and uncertain nature of the prime mover, the wind [3,4]. Many works have been done on various aspects of the DFIG WECS, such as the aerodynamic energy conversion, the electromechanical energy conversion, control underbalanced and imbalanced grid voltages, power electronic converters and their modulation schemes, and power evacuation to the grid. These lay emphasize on a single aspect at a time, but none has, to the authors' knowledge, tackled the complete operation of the system. This paper seeks to bridge these works for a complete picture into this multifaceted system.

This paper is divided into ten sections. Starting with an introduction in Section 1, Section 2 covers construction while Section 3 gives insight into the operation of the system. Section 4 presents the merits and demerits of the DFIG WECS. Section 5 gives modelling of the wind turbine and the DFIG while Section 6 covers grid connection requirements, control types, levels, and strategies. Section 7 covers possible faults and proposed solutions while simulation is handled in Section 8. Finally, discussion and conclusion are carried out in Sections 9 and 10, respectively.

\section{Construction}

The DFIG WECS consists of a wind turbine (WT) system connected to a DFIG through a gearbox for the purpose of extracting mechanical power from the air flows and converting it into electrical power. The wind turbine power output increases as to the cube of wind speed. Wind speed increases with increase in height; hence, horizontal axis wind turbines are mounted on a tower. The generator, gearbox, and associated control equipment are housed in a nacelle at the top of the tower. Some designs have some control equipment housed within the base of the tower. Figure 1 shows the components of a wind turbine.

The DFIG WECS utilizes three bladed horizontal axis wind turbines with active blade pitch capability. The gearbox consists of two helical and one planetary gear stages with the low speed shaft from the turbine rotor connected to the planetary stage and the high speed generator rotor shaft to the last helical stage as shown in Figure $2[5,17,18]$.

The DFIG has a wound stator which consists of three copper windings with a $120^{\circ}$ spatial offset in generators with two poles while those with four poles have six windings at $60^{\circ}$ offset [19]. The stator is connected, either directly or through a transformer depending on the level of its output voltage in relation to the grid voltage, to the grid bus. It also has a wound rotor which is brought out through slip rings and carbon brushes for connection to a power electronic converter (PEC) and then either directly or through a transformer, to the stator terminals.

The components in the rotor circuit include the following [14, 20-22].

2.1. $d v / d t$ Filter. It is a resistance in parallel with an inductance that is connected between the rotor windings terminals and the rotor side converter (RSC) terminals to protect the rotor windings against harmful effects from the RSC which include bearing currents, capacitive leakage currents, and degradation of insulation due to polarization effect by the resultant capacitive displacement current from sudden rise in voltage.

\subsection{Power Electronic Converter. It includes the following:}

(a) RSC. This is a voltage source converter (VSC) type, chosen over current source type due to its faster response to system 

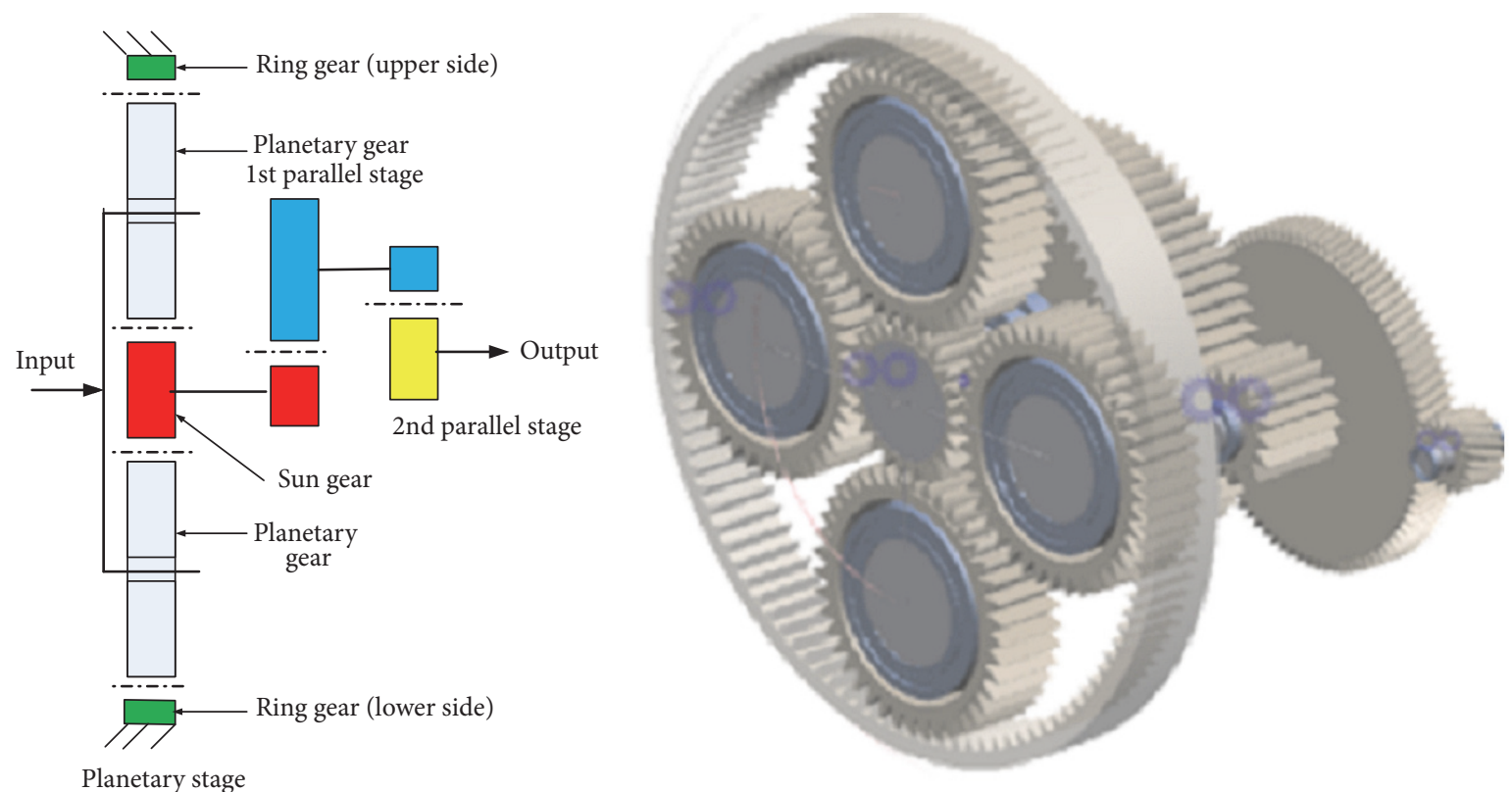

FiguRE 2: One-stage planetary and two-stage helical/parallel gear arrangement [6].

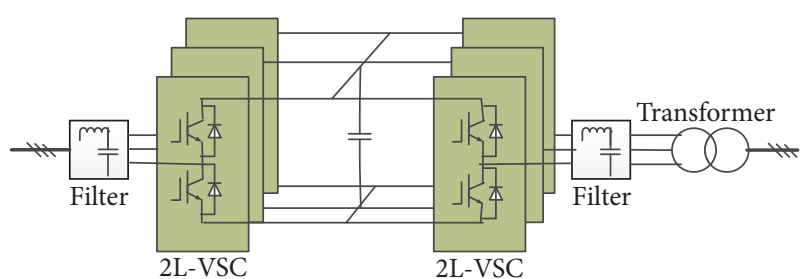

FIGURE 3: Two-level back-to-back voltage source converter [7].

changes and lower losses in the DC-link. It is composed of a rectifier bridge utilizing insulated gate bipolar transistors (IGBT) and diodes. It supplies magnetization current to the rotor. It also controls active and reactive generator power output by injecting currents of varying amplitude and frequency into the rotor windings. Slip power is also sent to the DC-link. The IGBTs switching is controlled by pulses which are generated by either sinusoidal pulse width modulation (SPWM) or space vector modulation (SVM) techniques.

(b) DC-Link. It links the RSC to the GSC as shown in Figure 3. It is composed of an energy storage capacitor or combination of several capacitors that try to maintain constant voltage at their terminals. A VSC is characterized by a high value of capacitance in the DC-link.

(c) Grid Side Converter (GSC). The GSC is a bidirectional rectifier bridge, utilizing IGBTs as the switching device, responsible for maintaining the DC bus voltage within certain limits by transferring the power from the rotor, which is stored in the DC-link capacitor, to the grid. It also exchanges reactive power with the grid by either absorbing reactive power from the grid or exporting reactive power to the grid as per the set value. Usually, its power factor is set at unity to minimize current flowing in it.

As DFIG WECS increase in individual size, the high power ratings have resulted in different converter configurations to accommodate the high currents and voltages with existing semiconductor device ratings. These include the following $[7,8,14,23]$.

(a) Two-Level Back-to-Back VSC. This is the most established solution with a simple structure and few components. Bulky filters are required to limit the high $\mathrm{dv} / \mathrm{dt}$ stresses on generator and transformer due to the only two voltage levels and to reduce the total harmonic distortion (THD) of grid voltages and currents.

(b) Parallel Connection of Two-Level Back-to-Back VSCs. This is as shown in Figure 4. It has the advantage of redundancy and hence increases reliability of the converter.

(c) Multilevel Topology. This is classified into the following:

(i) Three-level neutral point diode clamped (NPC) structure

(ii) Four-level flying capacitor clamped structure

(iii) Five-level cascade $\mathrm{H}$-bridge (CHB) connection which is bulky and complex as it requires many isolated DC sources

(d) Matrix Converters. A matrix converter, also called a cycloconverter, transfers AC supply directly into an AC load of a different frequency. It does not utilize a DC-link capacitor. It has lower harmonics and lower switching losses. 


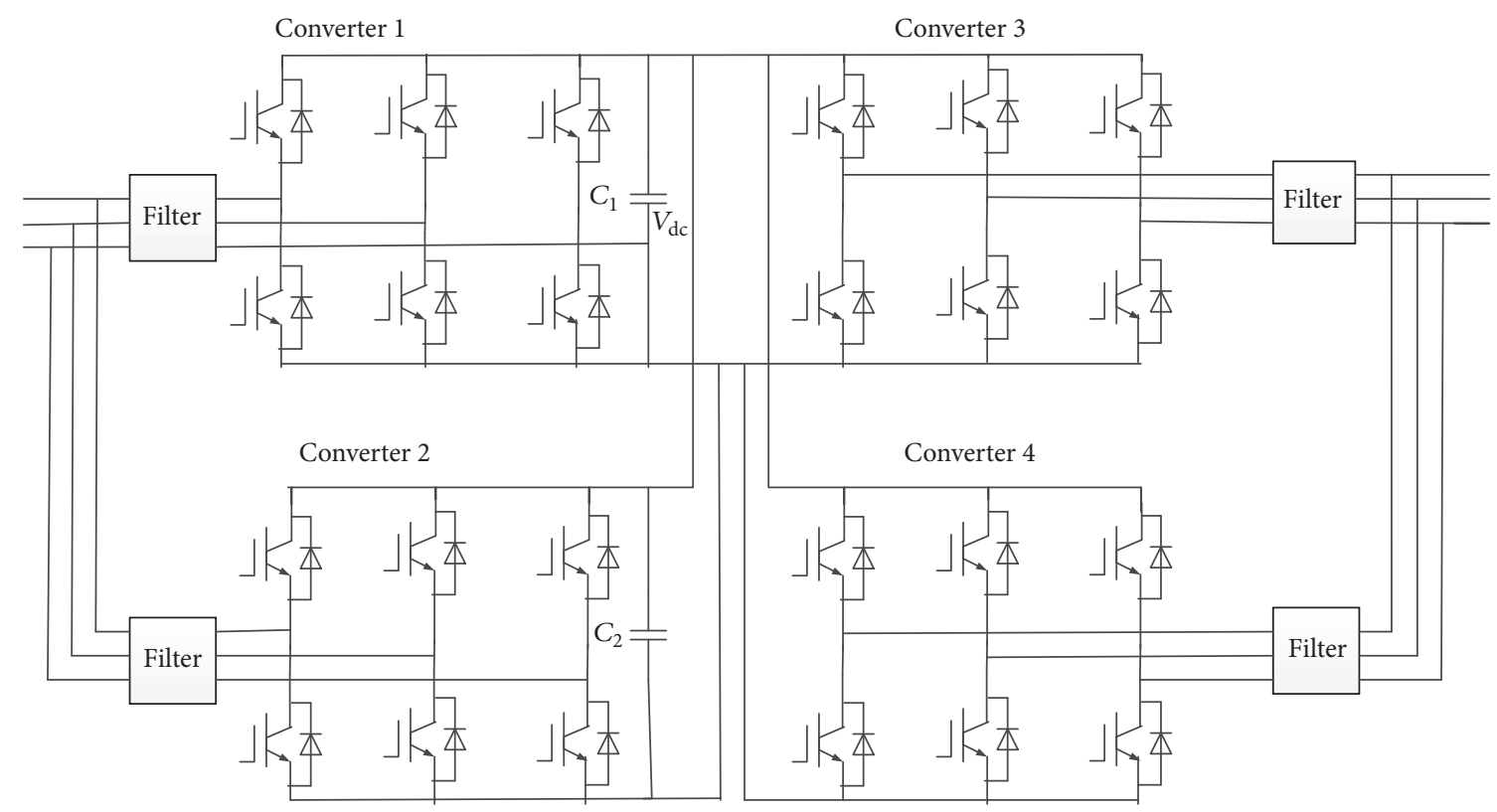

FIgURE 4: Two-level back-to-back VSC in parallel connection [8].

It however has higher conduction losses, limitation on output voltage, and poor protection during faults [2].

(e) Resonant Converters. The main topology, the natural clamped converter, consists of two two-level back-to-back VSCs with a circuit to provide resonance in between them.

(f) Tandem Converters. These consist of a two-level back-toback current source converter (CSC), designated the primary converter, in parallel with a two-level back-to-back VSC, and designated the secondary converter.

2.3. Harmonic Filter. The VSC produces harmonics, in multiples of the switching frequency, which cause distortion of the grid voltages and currents. The harmonics can be reduced by use of filters, either active, passive, or hybrid, and by control that utilizes RSC or GSC capacity [21, 24].

2.4. Electromagnetic Compatibility (EMC) Filter. The switching on and off of IGBTs causes interference over a wide signal spectrum. The interference signals can be transmitted or received by electrical connections through impedances between the emitting source and the susceptible equipment, through magnetic and electric fields causing capacitive and inductive connections, and by radiation. The EMC filter reduces these emissions to a level where other electrical devices can be operated in the vicinity without problems. The PEC itself must also not be affected by low levels of external interference to avoid giving rise to cases of dangerous operating states [19].

2.5. Converter Control Unit (CCU). It carries out the control of the various elements in the rotor circuit for coordinated, reliable, and accurate operation. The CCU is a programmable electronic device with various inputs from its own measurements and the WECS controller, and it sends out output signals to the elements to be controlled. It also has communication channels for remote sensing and control. Controls for the RSC and GSC under both normal conditions and grid disturbance conditions must ensure that predetermined setpoints are met.

\section{Operation}

The DFIG WECS is a variable speed wind turbine (VSWT) and is operated at varying speeds corresponding to the varying wind speeds from the cut-in speed (Point A) through the rated wind speed (Point $\mathrm{C}$ ) to the cut-out speed (Point E) as shown on the turbine torque characteristic curves in Figure 5.

Below cut-in speed (Point A), the machine is at standstill as the wind speed is too low for efficient and economical operation. Once sufficient wind is available, the turbine starts rotating and the machine starts generating power. The power coefficient is maintained constant at its maximum between points $\mathrm{B}$ and $\mathrm{C}$ to maximize power output as the wind speed increases. This is done by applying a maximum power point tracking (MPPT) strategy by which the turbine rotor speed is adjusted relative to the prevailing wind speed. During this period, the blade pitch angle is fixed at $0^{\circ}$. Beyond point $\mathrm{D}$, power regulation is introduced to ensure output power does not exceed rated power as wind speed continues rising. The power coefficient is lowered by pitching the rotor blades, hence reducing the speed of turbine rotation. At point $\mathrm{E}$, the cut-out speed, the machine is stopped by pitching the turbine blades out of the wind and applying the emergency brake to avoid structural damage due to high wind speeds. Running at high speeds can also result in high noise emission $[4,14]$. 


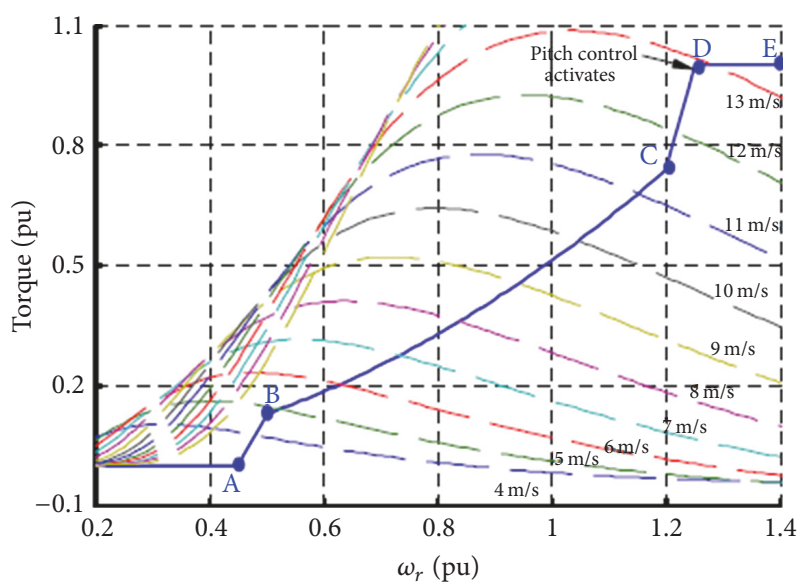

FIgURE 5: Turbine torque characteristics [9].

Whereas DFIG WECS have been utilized in stand-alone applications, the most common use is to supply power to the grid. The stator of the DFIG draws a reactive magnetizing current which is supplied either by the grid or the GSC. Since the DFIG is an asynchronous generator, its electromagnetic torque is developed when currents induced in the rotor windings set up a magnetic field which interacts with the stator field. These currents in the rotor are induced by both the voltage induced by the rotating stator field and the voltage supplied by the RSC. The stator field is of constant frequency set by the grid frequency. The rotor field, on the other hand, is of varying frequency which is dependent on the slip $[2,14]$.

The variable speed operation of the DFIG is possible due to use of the PEC. The bidirectional power transfer in the PEC enables two modes of operation [14]:

(i) Subsynchronous mode or partial load mode at below rated speeds: the stator of the DFIG supplies power to the grid and slip power to the rotor via the converters and slip rings.

(ii) Supersynchronous mode or nominal load range at above rated speed: both the stator output power and the rotor slip power are fed to the grid.

\section{Merits and Demerits}

The DFIG WECS has the following advantages [25-27]:

(i) Higher efficiency even at low wind speeds

(ii) Decoupled control of active $(P)$ and reactive $(Q)$ powers, hence being more responsive to system needs

(iii) Reduced acoustic noise making the system more environmentally acceptable

(iv) Reduced mechanical stresses which reduces maintenance costs and prolongs system lifetime

(v) Contributing to system power quality improvement without using external reactive compensation devices

(vi) Less cost as PEC is rated for lower power levels, usually $30 \%$
And it has the following disadvantages $[3,14,28]$ :

(i) The direct connection of the stator to the grid leaves the machine more vulnerable to system disturbances such as voltage dips and swells as the partially rated VSC is limited in its ability to withstand over currents and over voltages induced in it by stator fault currents due to the magnetic coupling between the stator and the rotor.

(ii) The VSC is a source of harmonics due to switching actions.

(iii) Use of PEC, gearbox, and slip rings introduces increased costs and maintenance needs, increased losses, and decreased reliability as they increase the number of components that can fail.

\section{Modelling}

The DFIG WECS has two main subsystems. The first handles harnessing of energy in the airflows and the subsequent conversion into rotational mechanical power. This subsystem includes the turbine rotors, the hub, the low speed shaft, the gearbox, and the high speed shaft that is connected to the generator rotor. The second subsystem carries out the conversion of the mechanical power into electrical power. This is handled by the generator and the PEC.

5.1. The Wind Turbine Model. The mechanical power extracted from the wind is given by $[11,29]$

$$
P_{m}=\frac{1}{2} A \rho V^{3} C_{p}(\lambda, \beta),
$$

where $P_{m}$ is mechanical power $(\mathrm{W}), A$ is area swept by turbine rotor $\left(\mathrm{m}^{2}\right), V$ is wind speed $(\mathrm{m} / \mathrm{s}), C_{p}$ is the power coefficient, $\rho$ is air density $\left(\mathrm{kg} / \mathrm{m}^{3}\right), \lambda$ is tip speed ratio (TSR) given as $\left(\omega_{m} * R / V\right), \beta$ is blade pitch angle (degrees), and $\omega_{m}$ is angular speed of wind turbine ( $\mathrm{rad} / \mathrm{s})$ given as $\left(p \Omega_{m} / 2\right)$, where $p$ is number of poles and $\Omega_{m}$ is rotor mechanical rotational speed $(\mathrm{rad} / \mathrm{s})$.

And the mechanical torque developed by the wind turbine shaft is given as

$$
T_{m}=\frac{P_{m}}{\omega_{m}}=\frac{1}{2} A \rho V^{2} C_{p}(\lambda, \beta) \frac{R}{\lambda},
$$

where $T_{m}$ is mechanical torque $(\mathrm{N} \cdot \mathrm{m})$ and $R$ is radius of turbine rotor $(\mathrm{m})$. The power coefficient is given by

$$
C_{p}(\lambda, \beta)=0.5\left(\Gamma-0.02 \beta^{2}-5.6\right) e^{-0.17 \Gamma},
$$

where

$$
\Gamma=\frac{R}{\lambda} \frac{(3600)}{(1609)} .
$$

5.2. The DFIG Model. The DFIG park model in the $d-q$ reference frame, assuming sinusoidal flux, constant winding resistance, and neglecting magnetic saturation, is given in Figure 6. 

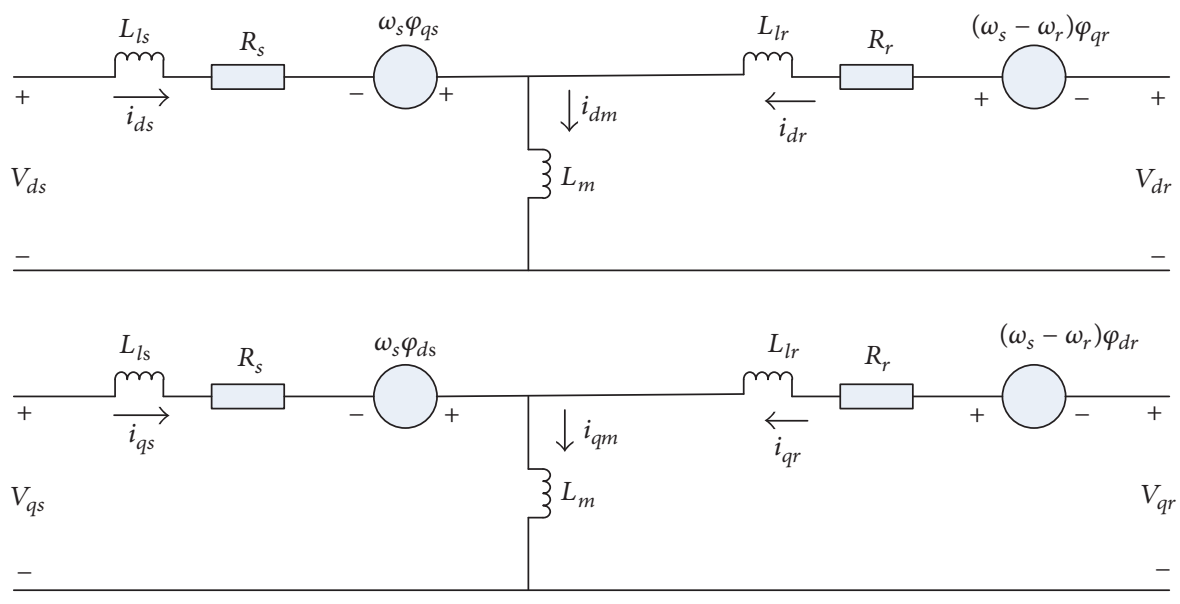

FIGURE 6: DFIG equivalent circuit in $d-q$ reference frame [10].

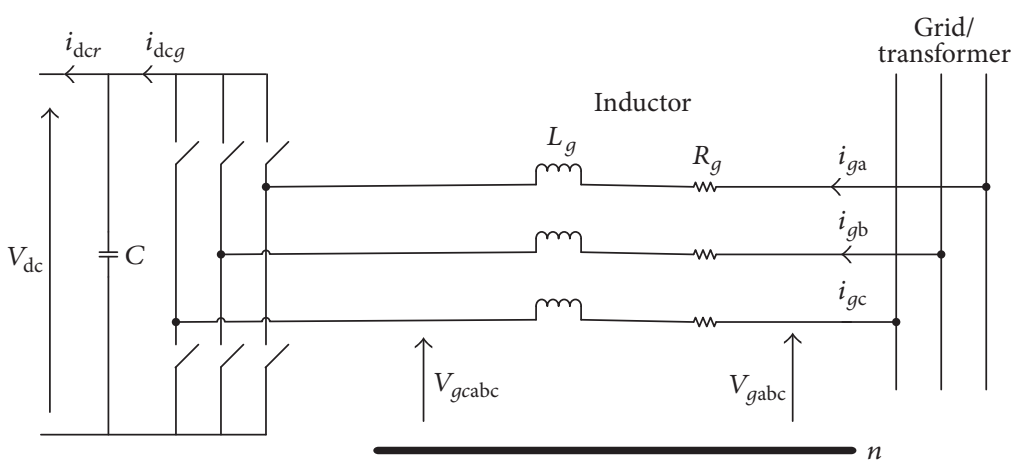

Figure 7: Schematic of GSC connection to grid [11].

The equations relating the DFIG park model stator and rotor voltages and fluxes are

$$
\begin{aligned}
& v_{d s}=R_{s} i_{d s}-\omega_{s} \varphi_{q s}+\frac{d \varphi_{d s}}{d t} \\
& v_{q s}=R_{s} i_{q s}+\omega_{s} \varphi_{d s}+\frac{d \varphi_{q s}}{d t} \\
& v_{d r}=R_{r} i_{d r}-\omega \varphi_{q r}+\frac{d \varphi_{d r}}{d t} \\
& v_{q r}=R_{r} i_{q r}+\omega \varphi_{d r}+\frac{d \varphi_{q r}}{d t},
\end{aligned}
$$

where $v$ are voltages $(\mathrm{V}), i$ are currents $(\mathrm{A}), R$ are resistances $(\Omega)$, and $\varphi$ are flux linkages $(\mathrm{V} \cdot \mathrm{s})$. Indices $d$ and $q$ indicate direct and quadrature axis components, respectively, while $s$ and $r$ indicate stator and rotor quantities, respectively, and $\omega_{s}$ is grid electrical angular speed, $\omega_{r}$ is rotor electrical angular speed and slip speed, and $\omega$ is given by $\omega_{s}-\omega_{r}$.

The direct and quadrature stator and rotor flux components are decoupled magnetically and are given by

$$
\begin{aligned}
& \varphi_{d s}=L_{s} i_{d s}+L_{m} i_{d r} \\
& \varphi_{q s}=L_{s} i_{q s}+L_{m} i_{q r}
\end{aligned}
$$

$$
\begin{aligned}
& \varphi_{d r}=L_{r} i_{d r}+L_{m} i_{d s} \\
& \varphi_{q r}=L_{r} i_{q r}+L_{m} i_{q s},
\end{aligned}
$$

where $L_{s}=L_{l s}+L_{m}$ and $L_{r}=L_{l r}+L_{m}, L_{l s}$ and $L_{l r}$ are stator leakage and rotor self-inductances, and $L_{m}$ is mutual inductance $(\mathrm{H})$.

The equivalent circuit for the grid side converter connection to the grid is given in Figure 7.

The voltage across the inductor is given, in the $d-q$ reference frame, by

$$
\begin{aligned}
& v_{g d}=R_{g} i_{g d}+L_{g} \frac{d i_{g d}}{d t}-\omega_{s} L_{g} i_{g d}+v_{g c d} \\
& v_{g q}=R_{g} i_{g q}+L_{g} \frac{d i_{g q}}{d t}+\omega_{s} L_{g} i_{g q}+v_{g c q},
\end{aligned}
$$

where $V_{g c d}$ and $V_{g c q}$ are voltages at GSC output terminals while $V_{g d}$ and $V_{g q}$ are voltages at the grid.

\section{Control}

6.1. Grid Utility Operator's Specifications. Control for DFIG WECS is aimed at power production that meets the grid 


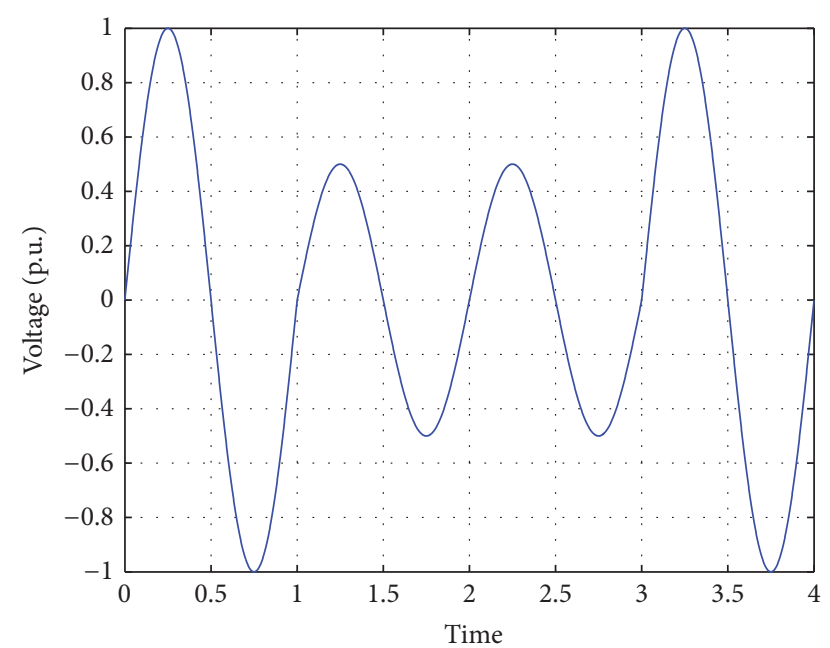

Figure 8: Voltage sag (dip) [12].

utility operator's specifications. These usually vary as to the operator, based on the complexity of the grid system. IEEE standard 1549 defines the basic requirements for integrating distributed generation units including wind power to the utility grids. Common grid connection requirements include $[2,19,27,30-34]$ the following.

(a) Fault Ride-Through (FRT). DFIG WECS are impacted by faults from the grid. These include frequency fluctuations, voltage sags, and voltage swells. FRT capability is critical system requirements for wind farms as disconnection of the wind farm on occurrence of a fault is no longer an option since the sudden loss of a large source of active power can result in cascade trip of other plants due to undervoltage and/or underfrequency due to power-load mismatch in the system. Thus, the main aim of FRT requirement is the instantaneous resumption of active power as soon as the fault is cleared [3]. IEEE std. 1159/95 defines voltage sag as a reduction of between 0.1 to 0.9 p.u. of the voltage and current (on an rms basis) at the power frequency for any duration ranging from 0.5 cycles to 1 minute. The amplitude is the remaining voltage value during the sag. On the other hand, IEC defines a voltage dip as a sudden voltage reduction at any point in the electrical system lasting from anywhere between half a cycle to a few seconds [35]. Figure 8 shows the waveform of a voltage sag.

Voltage swell as defined by IEEE 1159/95 is the increase in the RMS voltage level to 1.1 p.u-1.8 p.u. of nominal, at the power frequency, for durations of 0.5 cycles to 1 minute. Figure 9 shows the waveform of a voltage swell.

There are two subtypes of FRT.

(i) Low-Voltage Ride-Through (LVRT). Some grid codes also include zero-voltage ride-through (ZVRT), where the nominal voltage drops to zero, under LVRT. Voltage sags result from sudden loss of large generating units, switching in of large loads such as induction motors, and energizing of transformers and system faults such as short circuits and faults to ground $[23,36,37]$. On occurrence of voltage sag,

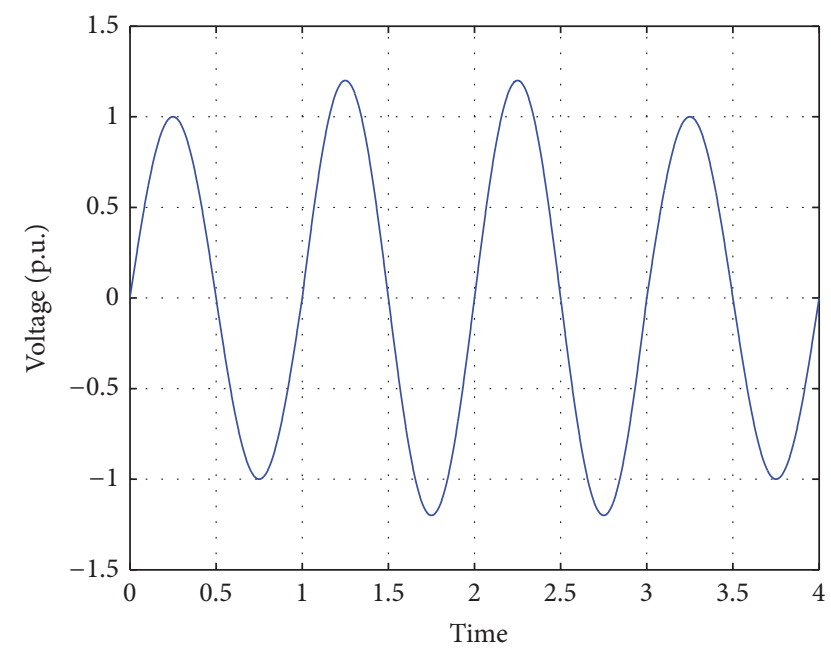

Figure 9: Voltage swell [13].

the WECS must remain connected for a given set time before disconnecting. In some cases, the WECS must help support grid voltage during the fault. LVRT curves for four countries are given in Figure 10.

(ii) High-Voltage Ride-Through (HVRT). Voltage swells result from single-phase short-term interruptions, reactive power overcompensation from capacitor banks, lightning strikes, or switching off of large loads such as in response to voltage sag $[23,38,39]$. When voltage goes above its upper limit, usually at $1.1 \%$ though being set at $1.3 \%$ for Spain and Australia [15], the WECS must stay connected for a given period of time before disconnecting.

Since voltage sags are more frequent than swells, LVRT is given greater focus than HVRT.

(b) Active Power $(P)$ Control. The WECS must provide active power control to ensure stable system frequency and avoid overloading of transmission lines. The ramp rate should also be within the set range.

(c) Reactive Power (Q) Control. Dynamic reactive power control capability is required as the power factor and reactive power balance must be maintained in the desired range.

(d) Voltage Regulation. The voltage at each WECS terminal must be maintained at a constant value.

(e) Voltage Operating Ranges. The WECS must operate within typical grid voltage limits.

(f) Frequency Control. This entails frequency regulation capability so as to maintain desired grid frequency.

(g) Frequency Operating Ranges. The WECS must operate within typical grid frequency limits.

(h) Power Quality. The WECS outputs in terms of voltage fluctuations which could result in flicker and voltage/current harmonics are limited to within set ranges. 


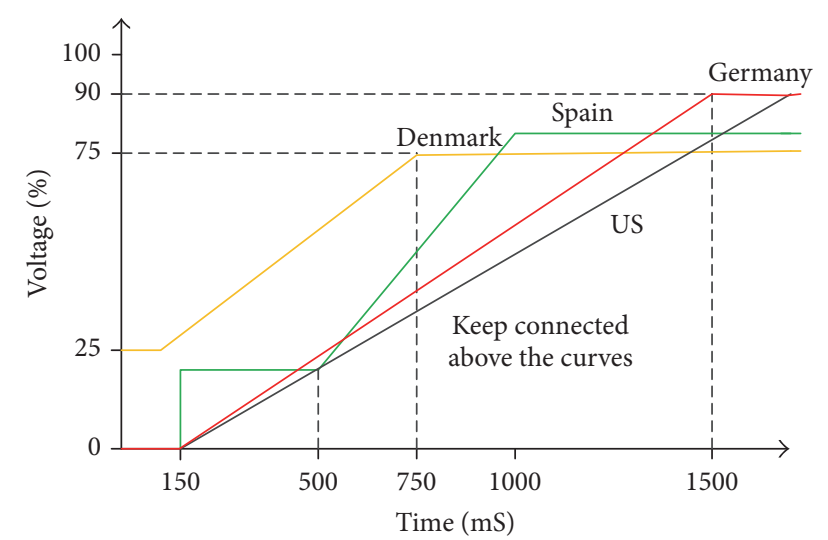

FIgURE 10: Curves for low-voltage ride-through requirements for different countries [7].

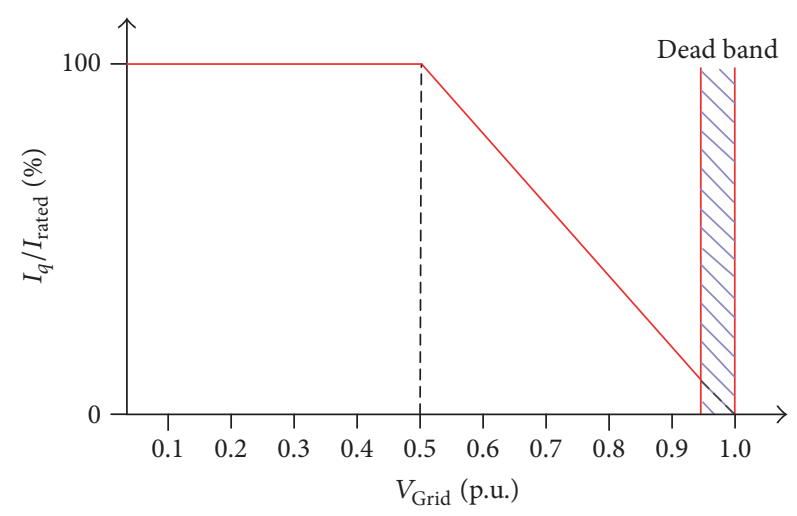

FIGURE 11: German and Danish grid code reactive current requirements during sags [10].

(i) Stability. The WECS must be able to ride out transient disturbances that result from short circuits and faults causing momentary power imbalances. This is because if WECS disconnect at such times, they worsen the situation with the loss of power production causing system instability. However, the generator response must go beyond just securing machine operation during the fault. Instead, the response must assist in maintaining and even improving the system stability. In Germany, the transmission operator E.oN has an LVRT requirement that, for voltages below 0.5 p.u, the wind turbine must supply, within $20 \mathrm{mS}, 100 \%$ of its rated current as reactive current to help support the grid [40,41]. This is shown in Figure 11.

(j) Wind Farm Modelling and Verification. Models and system data of the WECS are used to carry out simulations to investigate interactions between the wind farm and the grid. Monitoring equipment must also be set up to verify actual behaviour during faults.

(k) Communication and External Control. The WECS must provide certain parameters to the grid operator for proper operation of the power system. Remote connection and disconnection must also be possible.
6.2. DFIG WECS Control Types and Levels. The control and supervision of a wind turbine are automated so as to realize benefits such as reduced cost of operation, increased staff safety, and increased energy yield. It is handled by three different systems: supervision, control, and safety [4, 14, 19, 42].

6.2.1. The Supervisory System. The management or supervisory system provides up-to-date desired system values and reacts to medium and long-term variations in ranges from minutes to years. It carries out tasks such as monitoring wind and other loading conditions, sending information to the control system, monitoring operation for safe conditions, monitoring grid conditions, actuating emergency systems, and switching between operating states that facilitate connection and disconnection to the grid.

The supervisory system operates in two modes:

(i) Continuous fault monitoring: to facilitate preventive maintenance and planned system service

(ii) Emergency shutdown: for cases where there are high winds, catastrophic failure, and other emergencies

It also incorporates a failsafe system so that in case of power failure to either the controls, the control logic, or the sensors, the turbine can be safely brought to a stop or shutdown state.

Except in emergency situations, management system decisions are always transferred to the final component under control through the control system. The management system is thus hierarchically above the control system, acting only when necessary to direct the turbine operations both collectively in case of a wind farm and individually. For wind farms, the management system monitors the overall operation of the farm as well as that of specific machines and is called a supervisory control and data acquisition system (SCADA).

6.2.2. The Control System. The control system acts under the supervision of a management system. It deals with direct intervention measures on the turbine, the gearbox, the drive shaft, and the generator, collectively referred to as the power drive train, to create adjustments that result in the output meeting the set limits on a point by point basis. The control system operates with regard to functionality and integration of the turbine, taking into consideration the characteristics of each component and its reaction to external effects as well as adjustment efforts. It thus handles the internal conditions of the system by maintaining values specified for the turbine by the management system. It acts continuously as it has to react to fast changes in wind speed and generator load for as long as the system dynamics are within limits set by the management system. The control system operation is aimed at regulating the turbine power in high winds and optimizing it in low speed winds. 


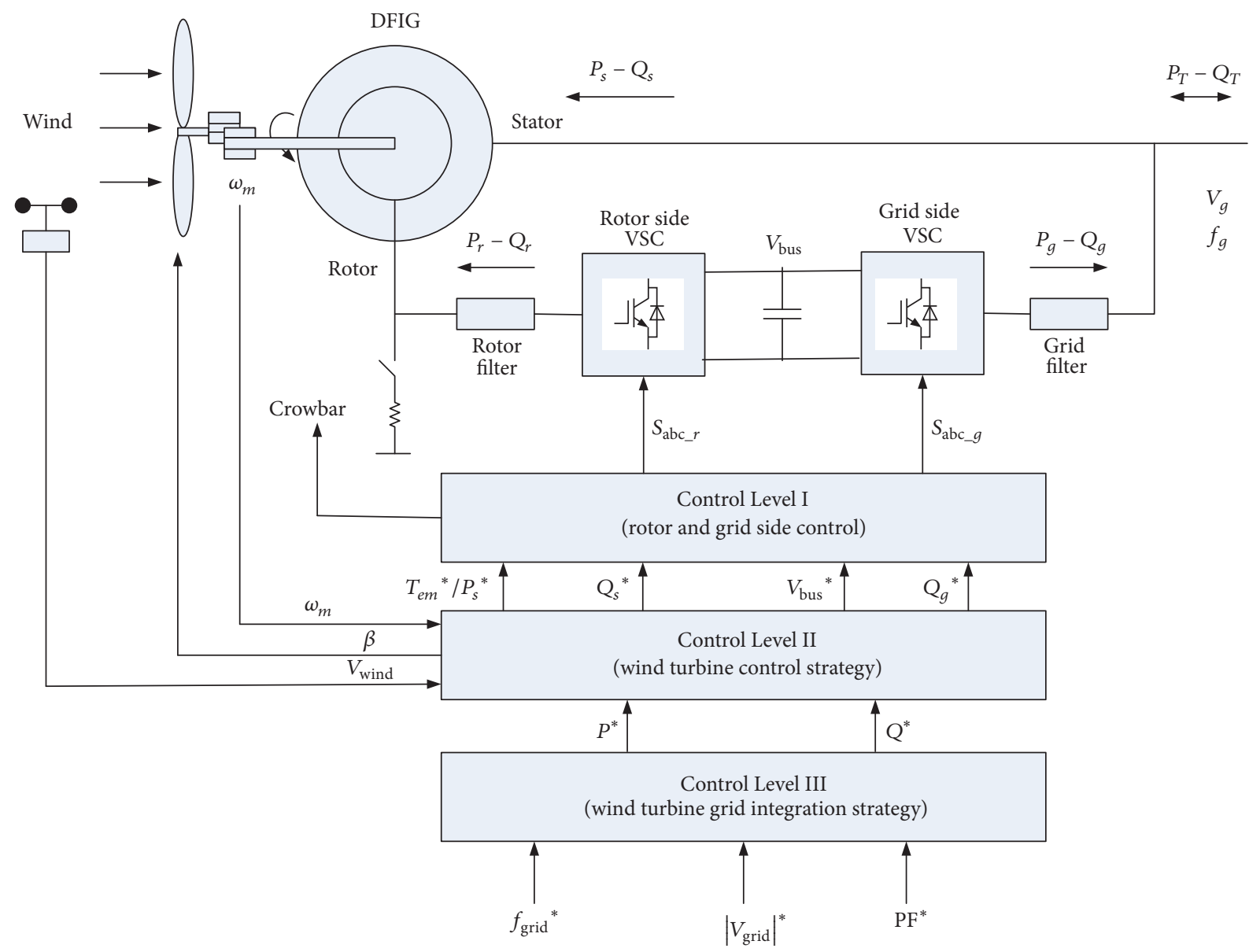

FIGURE 12: Conceptual diagram for DFIG wind turbine with partial scale power converter showing control strategy levels [14].

The five major processes to be controlled in a wind turbine are as follows:

(i) Development of aerodynamic torque: which is at the rotor blades and hence includes control of blade pitch and rotor orientation

(ii) Development of generator torque: by controlling mechanical inputs to the generator such as by change of shaft speed and controlling the air-gap rotating magnetic field

(iii) Conversion of electrical current into motion: which involves use of electrical signals to effect actions such as blade pitch angle change, rotor/yaw orientation control, or applying brakes (brake torque control)

(iv) Conversion of electrical power: the conversion of power generated to desired voltage, frequency, and power factor by use of PEC

(v) Conversion of wind energy to electrical power: which is the overall process, incorporating all the above 4 processes but, in addition, involving the management system inputs

6.2.3. The Safety System. Due to the high cost of WECS installations, as well as for grid system and personnel safety, a safety system that is independent of the main control system is essential. It functions to bring the turbine to a safe condition in the event of a serious problem by bringing the turbine to a stop or slow idling speed with the blades feathered and the generator switched off. It acts as a backup system when the main control system fails or when activated by an operatorcontrolled emergency stop button.

Control strategy for DFIG WECS is on three interlinked levels as shown in Figure 12 [25].

(a) Level I. This controls power flow from the DFIG, both from stator and from rotor, to the grid using the PEC. The converter control is divided into RSC control and GSC control [43].

(i) RSC control: RSC has decoupled control of stator active power (electromechanical torque) and the stator reactive power. It has a two-stage controller, oriented on either stator flux or grid/stator voltage reference frame. It has a faster inner current control loop and a slower outer power control loop.

(ii) GSC control: it aims at maintaining the DC-link capacitor voltage at a set value in addition to maintaining the desired converter power factor. It has a two-stage controller on grid/stator voltage oriented 
reference frame where the $d$-axis current component controls the active power and hence the DC-link voltage on the outer slower loop while the $q$-axis current component controls the reactive power on the faster inner loop.

(b) Level II. This handles control of conversion of wind energy in the airflows into mechanical energy by the turbine rotor, always aiming at maximum power production except when a reserve capacity is ordered by Level III control. It receives its set-points from Level III control and sends control set-points to Level I control.

(c) Level III. This is the highest level of control as it controls integration with the grid and provides control related to the grid voltage, power factor, and frequency as well as responding to grid operator requirements in terms of active and reactive power demands. It is similar to the wind farm control system but deals only with individual WECS values.

6.3. DFIG WECS Control Strategies. Many control strategies are proposed and they include the following.

6.3.1. Vector Oriented Control (VOC). This has the VSC being either voltage controlled (VC-VSC) or current controlled (CC-VSC) and being based on either of the following reference frames.

(i) Grid/stator voltage oriented frame [44]: in stator voltage oriented (SVO) control, the $d$-axis of the synchronous frame is fixed on the stator voltage vector. Thus, $V_{s}=V_{d s}$ and $V_{q s}=0$. Stator active and reactive powers are derived as

$$
\begin{gathered}
P_{s}=v_{d s} i_{d s}=\frac{v_{d s}\left(\varphi_{d s}-L_{m} i_{d r}\right)}{L_{s}} \\
Q_{s}=-v_{d s} i_{q s}=-\frac{v_{d s}\left(\varphi_{q s}-L_{m} i_{q r}\right)}{L_{s}} .
\end{gathered}
$$

Hence, the active power is controlled by adjusting $i_{d r}$ and reactive power by adjusting $i_{q r}$, respectively. This is possible through control of $V_{d r}$ and $V_{q r}$. In the GSC, the $d$-axis current controls the active power and so indirectly the DClink voltage, whereas the $q$-axis current controls the reactive power.

(ii) Stator flux oriented frame [11, 45]: in stator flux orientation, the reference frame rotates synchronously with respect to the stator flux such that the reference frame has its $d$-axis simultaneously overlapping the axis of the stator winding flux. Hence, $\omega=\omega_{s}$ and $\varphi_{q s}=0$. The dynamic equations then change to

$$
\begin{aligned}
& v_{d s}=R_{s} i_{d s}+\frac{d \varphi_{d s}}{d t} \\
& v_{q s}=R_{s} i_{q s}+\omega_{s} \varphi_{d s} \\
& \varphi_{d s}=L_{s} i_{d s}+L_{m} i_{d r} \\
& \varphi_{q s}=0=L_{s} i_{q s}+L_{m} i_{q r} .
\end{aligned}
$$

The electromagnetic torque and stator active power are obtained as below where $p$ is number of poles:

$$
\begin{aligned}
& T_{e}=\frac{3}{2} \frac{p}{2} \varphi_{d s} i_{q r} \\
& P_{s}=\frac{3}{2} \frac{p}{2} \omega_{s} \varphi_{d s} i_{q r} .
\end{aligned}
$$

But DFIG stator flux is restricted by the constant magnitude and frequency of the stator voltage; hence, torque control and thus active power can be achieved by controlling $i_{q r}$. Also, with stator flux remaining unchanged, reactive power is derived as

$$
Q_{s}=\frac{3}{2} \frac{p}{2} \omega_{s} \varphi_{d s} i_{d s}
$$

Regardless of magnitude and direction of rotor power, the GSC keeps the DC-link voltage constant. The DC-link voltage balance equation is thus

$$
C V_{\mathrm{dc}} \frac{d V_{\mathrm{dc}}}{d t}=P_{r}-P_{g},
$$

where $C$ is the DC-link capacitance $(\mathrm{F}), P_{r}$ is active power from rotor into RSC (W), and $P_{g}$ is active power flow into the grid from the GSC (W). The capacitor current is

$$
i_{\mathrm{dc}}=C \frac{d V_{\mathrm{dc}}}{d t}=\frac{3}{4} m i_{g c d}-i_{\mathrm{dc} r}
$$

where $i_{g c d}$ is $d$-axis current flowing between the grid and the GSC (A), $i_{\mathrm{dcr}}$ is the rotor side DC current (A), and $m$ is the pulse width modulation index of GSC. The reactive power flow into the grid from the GSC is given by

$$
Q_{g}=\frac{3}{2} V_{g} i_{g c q},
$$

where $V_{g}$ is magnitude of grid phase voltage (V) and $i_{g c q}$ is $q$-axis current of GSC (A). As such, DC-link voltage can be controlled by adjusting $i_{\text {gcd }}$ while reactive power from GSC is controlled by adjusting $i_{g c q}$.

(iii) Combination where the RSC is under stator flux orientation while the GSC is under stator voltage oriented frame [46]

(iv) Rotor flux oriented reference frame [47, 48]

6.3.2. Direct Torque Control (DTC) [49]. Since the electromagnetic torque is related to the stator flux, the converter switch state is obtained from a look-up table based on the position of stator flux vector. It has a simple control structure and good dynamic response and greatly reduces machine torque oscillations.

6.3.3. Direct Power Control (DPC). The error between calculated instantaneous active and reactive power and their estimated values is used to select, from a switching table, the converter switching state. This has a simple control structure, good dynamic response, and improved robustness 
to machine parameter variations. It however requires a high frequency sampling for satisfactory performance and has variable switching frequency. The variable switching frequency makes design of appropriate filters difficult. It can be grid/stator voltage oriented or stator flux oriented [31, 50, 51].

It is noted that VOC is achieved using proportionalintegral (PI) controllers while proportional-integral plus resonant $(\mathrm{PI}+\mathrm{R})$ controllers give improved performance. VOC relies heavily on machine parameters and hence is not robust to machine variations. VOC introduces lower THD with satisfactory steady state performance but the direct methods are faster in dynamic response. DPC however has high power losses. Also, estimation of stator voltage space vector is easier than that of stator flux space vector $[25,52]$.

6.3.4. Sliding Mode Control (SMC) [53]. SMC is a nonlinear control technique derived from variable structure control. It includes several different continuous functions for mapping plant state to a control surface. The switching between the different functions is determined by plant states represented by a switching function and so can change at any time during system operation unlike in feedback control.

The steps of SMC design are as follows:

(i) Selecting a sliding surface that models the desired closed loop performance

(ii) Designing a control law such that the system state trajectory is forced towards the sliding surface [54]

(iii) Designing a boundary layer of the switching function such that the control of the state variables is as follows:

(a) Outside of the boundary layer: being constrained to keep discontinuous switching

(b) Inside of boundary layer: the locus of state variables being restricted by a linear constraint

The thicker the boundary layer, the better the control. This however increases the control gain and reduces the inhibitory effect on chattering. It could also result in steady state error [55].

For a nonlinear system [37],

$$
\dot{X}(t)=f(x, t)+B(x, t) * U(x, t),
$$

where $X$ is the state vector and $U$ is the control vector.

The control law can then be defined as

$$
U_{d q}=U_{\mathrm{eq}}+U_{n}
$$

where the Signum function is defined by $U_{n}=-K_{f} *$ $\operatorname{sign}(S(x, t))$ given that $U_{d q}$ is the control vector, $U_{\text {eq }}$ is the equivalent control vector which is valid only in the sliding surface, $U_{n}$ is the switching part of control (the correction vector), and $K_{f}$ is the controller gain.

SMC is superior to PI controllers used in VOC in that it $[53,54,56,57]$

(i) improves performance of the system against unmodeled dynamics, (ii) reduces overshoot and transient time,

(iii) is robust to external disturbances and machine parameter changes due to generator temperature rise, magnetic saturation, and skin effect, among others; this is because the control signals only depend on the selected switching variables states,

(iv) has simple implementation as it does not require the decomposition of the voltage and current sequences in the VSC or use of a phase locked loop (PLL) to obtain the grid voltage positive sequence; this avoids time consuming computations as well as the challenges of the PLL losing synchronism with system frequency following a fault $[40,58,59]$,

(v) has better reference tracking.

SMC has a problem with chattering, the high frequency oscillation of system state trajectory around the sliding surface. Chattering results in undesirable mechanical stresses [60]. This is caused by idealized modelling of the system, time delay of actual switching, and the discretization of digital control [55]. It can be reduced by using a finite gain $K_{f}$ with a small boundary [54].

There are many different subtypes of SMC which aim at reducing the shortcomings of SMC while amplifying its advantages to various degrees of success. These include discrete time SMC, terminal SMC, back stepping terminal SMC, integral terminal SMC, nonsingular SMC, fast terminal SMC, and super twisting SMC.

Various combinations of the four control strategies above are also utilized with the aim of taking advantage of the strong points of each of the control strategies in the combination while minimizing their shortcomings. Other control strategies for the whole converter or just either the RSC or GSC are proposed for use in conjunction with the methods stated above. These include the following.

(a) Fuzzy logic control (FLC): it is used for control of nonlinear, uncertain, and adaptive systems with parameter variation. It does not strictly require a mathematical model of the plant. Its control rule is qualitatively expressed on the basis of logic-language variation [56]. A fuzzy logic controller can be used to measure power and rotational speed and then optimally increment the operating speed to attain the required power output change. This avoids use of a wind speed sensor with its associated cost and implementation difficulty. This allows optimal rotor speed reference tracking [60]. FLC can be used in conjunction with the SMC to generate the value of the gain $K_{f}$

(b) Predictive direct current control (PDCC) [52]

(c) Internal model control (IMC) [61]

(d) Artificial neural networks (ANN) [57]

(e) Genetic algorithm (GA) [62]

(f) Particle swarm optimization (PSO) [63] 
TABLE 1: DFIG WECS internal faults, their effects, and proposed solutions.

\begin{tabular}{|c|c|c|c|c|}
\hline $\begin{array}{l}\text { Component } \\
\text { affected }\end{array}$ & Effect & Causes & Risk & Solutions \\
\hline \multirow{3}{*}{ Turbine } & Blade fracture & $\begin{array}{l}\text { Excessive loading from } \\
\text { wind gusts or icing }\end{array}$ & $\begin{array}{l}\text { Blade pieces and } \\
\text { dislodged ice flying } \\
\text { off risking damage to } \\
\text { other turbines and } \\
\text { personnel }\end{array}$ & $\begin{array}{l}\text { Emergency shutdown in high gust or } \\
\text { ice situations } \\
\text { Deicing systems incorporated in rotor } \\
\text { blades }\end{array}$ \\
\hline & Lightning strike & Strikes by lightning & Fire & $\begin{array}{l}\text { Lightning earthing system } \\
\text { incorporated in rotor blade }\end{array}$ \\
\hline & Hydraulic failure & $\begin{array}{l}\text { Control system } \\
\text { malfunction, } \\
\text { environmental } \\
\text { degradation }\end{array}$ & $\begin{array}{l}\text { Loss of timely control } \\
\text { Fire from leaking oil }\end{array}$ & Timely preventive maintenance \\
\hline Gearbox & Gearbox failure & Insufficient lubrication & $\begin{array}{l}\text { Worn or fractured } \\
\text { gears, } \\
\text { fire }\end{array}$ & $\begin{array}{l}\text { Use of sufficient and correct high } \\
\text { quality lubricants } \\
\text { Sufficient lubricant cooling system }\end{array}$ \\
\hline Generator & $\begin{array}{l}\text { Windings open } \\
\text { circuit, } \\
\text { winding insulation } \\
\text { failure }\end{array}$ & $\begin{array}{l}\text { High operating } \\
\text { temperatures, } \\
\text { transient voltages and } \\
\text { currents }\end{array}$ & $\begin{array}{l}\text { Reduced or stoppage } \\
\text { of power production }\end{array}$ & $\begin{array}{l}\text { Regulation of voltages and currents to } \\
\text { ensure stable operating temperatures }\end{array}$ \\
\hline \multirow{2}{*}{ PEC } & $\begin{array}{l}\text { Semiconductor device } \\
\text { failure } \\
\text { Failure of bond wire } \\
\text { connection }\end{array}$ & Thermal cycling & $\begin{array}{l}\text { Output power } \\
\text { fluctuations }\end{array}$ & $\begin{array}{l}\text { Control that reduces thermal } \\
\text { variations }\end{array}$ \\
\hline & $\begin{array}{l}\text { DC-link capacitor } \\
\text { failures }\end{array}$ & $\begin{array}{l}\text { Voltage fluctuations, } \\
\text { harmonic currents }\end{array}$ & $\begin{array}{l}\text { Reduced output } \\
\text { power, } \\
\text { increased fluctuations } \\
\text { in output currents }\end{array}$ & $\begin{array}{l}\text { Control that reduces voltage variations } \\
\text { across the capacitor }\end{array}$ \\
\hline
\end{tabular}

\section{Faults}

The main challenge in operation of the DFIG WECS is continued operation under fault conditions. Faults could originate internally from the machine or externally from the grid. Table 1 gives a summary of the internal faults, their effects, and solutions proposed [6, 7, 19, 64-73].

Over $50 \%$ of internal faults are attributed to the PEC with $30 \%$ being from the DC-link capacitor. While the gearbox accounts for only $5 \%$ of failures, they are usually more costly, at times requiring complete gearbox replacements, and hence result in more downtime.

For external faults, voltage swells cause high temperatures in the generator windings. This results in insulation degradation and eventual failure leading to inter-turn short circuits. High voltages can also interfere with the control system [13]. Voltage sag results in high stator currents which in turn induce high rotor currents and reduced capability of the WECS to export power as to the square of the voltage drop. The latter leads to generator speed increase and increase in DC-link voltage. The two approaches to deal with effects of system faults are given in Table $2[3,15,21,34,46,50,74-90]$.

Some approaches utilize combinations of the solutions outlined above in a bid to cover the effects of severe faults. Examples include use of braking chopper with SRC [3] or with antiparallel thyristors [28]. Figure 13 shows application of a SMES for compensation.

\section{Simulation}

The DFIG WECS performance under different operating conditions is explored using simulations. Different computer tools are utilized and include power system computer aided design and electromagnetic transient including DC (PSCAD/EMTDC) [3], MATLAB/Simulink [91], power system simulation for engineering (PSS/E) [25], and electromagnetic transient program (EMTP-RV) [92]. Use of MATLABPSIM cosimulation [93] and DigSILENT power factory [94, 95] has also been reported in earlier works. Programs such as PSS/E are particularly suited for large power system analysis while PSCAD/EMTDC and EMTP-RV are applicable in large power system transient studies. The modelling is done to different levels of detail, with more detailed models taking more time to run. While high order models can be used, the 5th-order model is sufficient for detailed dynamic representation of the DFIG WECS while 3rd-order model can be obtained by neglecting stator flux transients. This limits its accuracy in modelling rotor current transient behaviour; however, the reduced complexity makes it best suited for large-scale wind farm simulations. The electromagnetic subsystem has very short time constants in comparison with the electromechanical subsystems which are modelled with the turbine and generator shaft masses, inertia, and damping either lumped (single-mass) or apart (two-mass). However, two-mass models are required for power system transient 
TABLE 2: DFIG WECS proposed solutions to faults from grid system.

\begin{tabular}{|c|c|c|c|c|c|}
\hline Approach & Aim & $\begin{array}{l}\text { Location of } \\
\text { application }\end{array}$ & $\begin{array}{l}\text { Method of } \\
\text { application }\end{array}$ & Examples & Methodology \\
\hline \multirow{3}{*}{ Control } & \multirow{3}{*}{$\begin{array}{l}\text { Keep WECS within } \\
\text { operation } \\
\text { constraints without } \\
\text { additional } \\
\text { components or } \\
\text { devices }\end{array}$} & \multirow{3}{*}{$\begin{array}{l}\text { Control } \\
\text { system }\end{array}$} & \multirow{3}{*}{ Software } & $\begin{array}{l}\text { Virtual } \\
\text { resistance/inductance }\end{array}$ & $\begin{array}{l}\text { Increased resistance and inductance in } \\
\text { virtual rotor circuit results in decreased } \\
\text { rotor currents and their decay times }\end{array}$ \\
\hline & & & & $\begin{array}{l}\text { Supplementary rotor } \\
\text { current (SRC) controller }\end{array}$ & $\begin{array}{l}\text { Introduces a multiplication factor } k \text { to the } \\
\text { measured rotor currents effectively } \\
\text { reducing the control variable to within } \\
\text { acceptable limits }\end{array}$ \\
\hline & & & & $\begin{array}{l}\text { Flux } \\
\text { damping/demagnetization }\end{array}$ & $\begin{array}{l}\text { Rotor current controlled to counteract } \\
\text { the stator flux negative sequence and DC } \\
\text { components of flux }\end{array}$ \\
\hline \multirow{10}{*}{ Hardware } & \multirow{10}{*}{$\begin{array}{l}\text { Maintain WECS } \\
\text { within operational } \\
\text { limits by addition } \\
\text { of components }\end{array}$} & \multirow{3}{*}{ Rotor } & Shunt & $\begin{array}{l}\text { Active crowbar, } \\
\text { passive crowbar }\end{array}$ & $\begin{array}{l}\text { High currents shunted through } \\
\text { dissipating resistors }\end{array}$ \\
\hline & & & Series & $\begin{array}{l}\text { Series dynamic braking } \\
\text { resistor (SDBR) }\end{array}$ & $\begin{array}{l}\text { High currents passed through dissipating } \\
\text { resistors }\end{array}$ \\
\hline & & & \multirow{3}{*}{ Shunt } & Braking chopper & $\begin{array}{l}\text { Charging currents passed through } \\
\text { dissipating resistors }\end{array}$ \\
\hline & & \multirow[t]{2}{*}{ DC-link } & & $\begin{array}{l}\text { Energy storage systems } \\
\text { (ESS), for example, battery } \\
\text { (BESS), } \\
\text { energy capacitor storage } \\
\text { (ECS), } \\
\text { superconducting magnetic } \\
\text { energy storage (SMES) }\end{array}$ & $\begin{array}{l}\text { Excess energy stored for later release } \\
\text { during system deficit }\end{array}$ \\
\hline & & & & SDBR & $\begin{array}{l}\text { Added resistance reduces fault currents to } \\
\text { within limits }\end{array}$ \\
\hline & & \multirow{3}{*}{ Stator } & \multirow[b]{2}{*}{ Series } & Series antiparallel thyristors & $\begin{array}{l}\text { Provide quick disconnection of stator } \\
\text { circuit to interrupt stator flux oscillations }\end{array}$ \\
\hline & & & & $\begin{array}{l}\text { Dynamic voltage restorer } \\
\text { (DVR), } \\
\text { series grid side converter } \\
\text { (SGSC) }\end{array}$ & $\begin{array}{l}\text { Maintain stator terminal voltage at } \\
\text { nominal values by injecting voltage }\end{array}$ \\
\hline & & & Series & $\begin{array}{l}\text { Flexible AC transmissions } \\
\text { systems (FACTS) devices } \\
\text { such as static synchronous } \\
\text { series compensator (SSSC), } \\
\text { DVR }\end{array}$ & $\begin{array}{l}\text { Maintain voltage at PCC nominal values } \\
\text { by injecting voltage }\end{array}$ \\
\hline & & \multirow[t]{2}{*}{ PCC } & Shunt & $\begin{array}{l}\text { FACTS devices such as } \\
\text { static synchronous } \\
\text { compensator (STATCOM), } \\
\text { static Var compensator } \\
\text { (SVC), SMES }\end{array}$ & $\begin{array}{l}\text { Maintain voltage at PCC nominal values } \\
\text { by injecting reactive power during sags. } \\
\text { SMES also draws reactive power during } \\
\text { swells }\end{array}$ \\
\hline & & & Hybrid & $\begin{array}{l}\text { FACTS devices such as } \\
\text { unified power flow } \\
\text { compensator (UPFC) }\end{array}$ & $\begin{array}{l}\text { Combined action of series and shunt } \\
\text { connected FACTs devices as given above }\end{array}$ \\
\hline
\end{tabular}

studies [96]. While individual machine performance is of interest, grid operators are more interested in the overall performance of the wind farm and make this a prerequisite for connection.

Figure 14 shows the MATLAB/Simulink model of a $9 \mathrm{MW}$ wind farm composed of 6 number $1.5 \mathrm{MW}$ DFIG machines, without FRT capability, connected through a $25 \mathrm{kV}$ feeder to a grid at $120 \mathrm{kV}$ [16]. Each machine has a turbine rated at 1.5 MW mechanical power with turbine power characteristics as depicted in Figure 5. The generators each have a nominal power rating of 1.5 MVA at $60 \mathrm{~Hz}$ and utilize power converters rated at 0.5 p.u. with a DC-link composed of a $10,000 \mathrm{pF}$ capacitor at $1200 \mathrm{kV}$. Figure 15 presents simulation results for normal operation with a step change increase in wind speed at $5 \mathrm{~s}$ where the blades are pitched at $20 \mathrm{~s}$ once rated power is achieved. In Figure 16, waveforms for case with a three-phase to ground fault applied at $25 \mathrm{~s}$ and removed after $150 \mathrm{~ms}$ are given. It is seen that the machines are disconnected due to overcurrents which go up to 1.25 p.u. In addition, the speed increases to 1.52 p.u., forcing further pitching of 


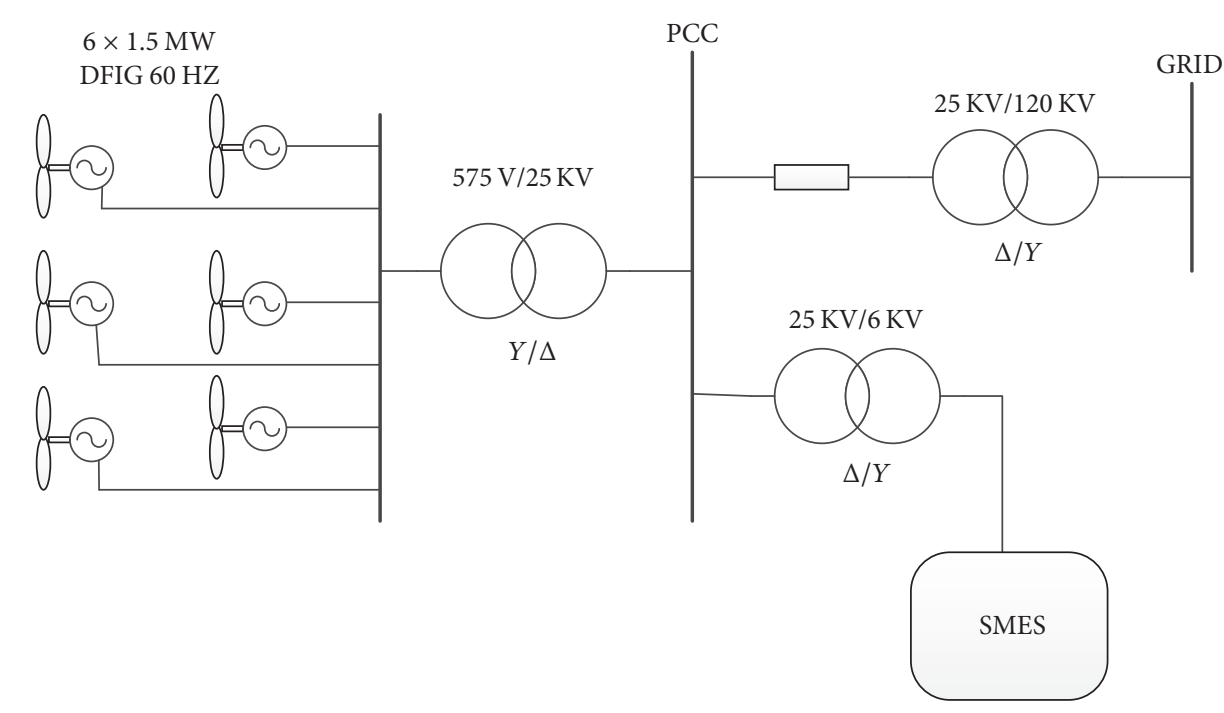

FIGURE 13: Single-line diagram showing SMES connection for reactive power compensation [15].

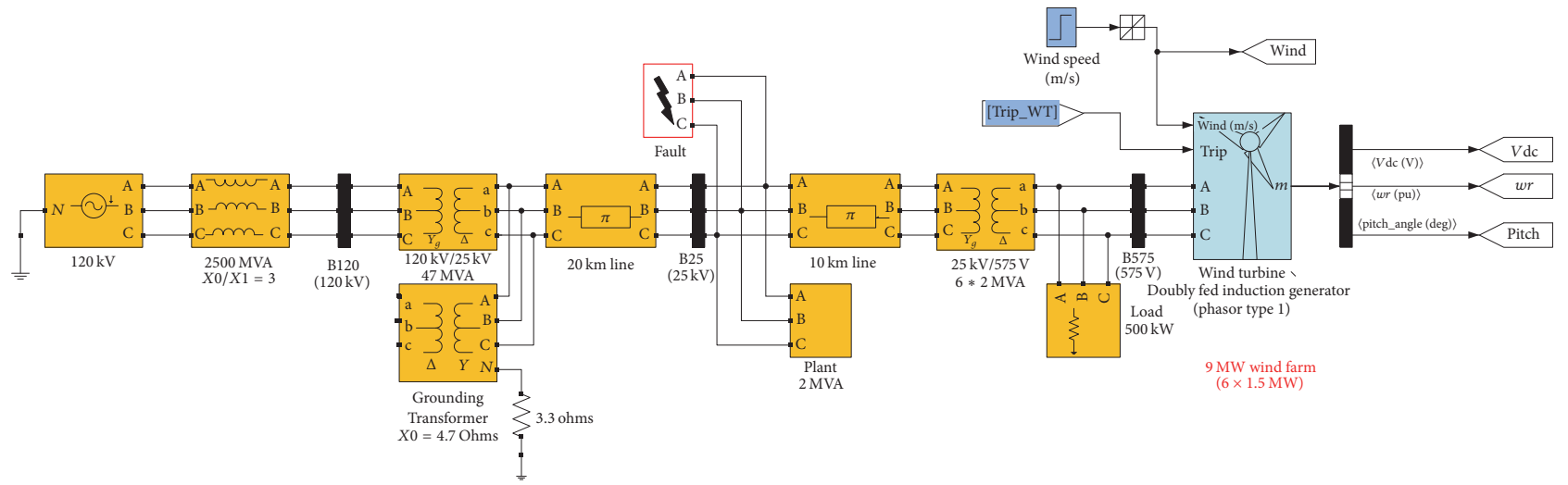

FIgURE 14: MATLAB/Simulink model of a 9 MW DFIG WECS wind farm [16].

the blades to reduce it. Thus, the need for FRT capability is clearly demonstrated. The simulations were done on a desktop computer running MATLAB 2010b.

\section{Discussion}

The DFIG WECS must meet the grid connection requirements which are only expected to become stricter as grid systems evolve further. For cost effectiveness, the DFIG WECS must operate at full efficiency during both steady and transient states while producing as much power as possible under the prevailing wind and grid conditions. As such, the choice of an appropriate control strategy is critical.

9.1. The Ideal Control Strategy. With the many proposed control strategies, and taking into consideration other aspects of the DFIG WECS such as operation with both MPPT and curtailed production, as well as operation during fault conditions, the qualities sought in deciding on an optimal solution include the following: (i) Independent of machine parameters: machine parameter variations cannot be completely avoided and occur from environmental changes such as seasonal air density changes, from component aging, or from change in operating conditions such as loading, steady state, or transient operation. A control system that does not rely on preset values such as a look-up table but instead relies on instantaneous values or has a learning ability can self-adjust for these variations giving a more accurate response.

(ii) Low component count: additional hardware and components introduce higher costs, increased space requirements, increased weight, increased control complexity and design, reduced system reliability as there are more components that can fail, increased maintenance, and challenges and limitations inherent in such components such as requirements for heat dissipation and introduction of delays and measurement errors [51]. 


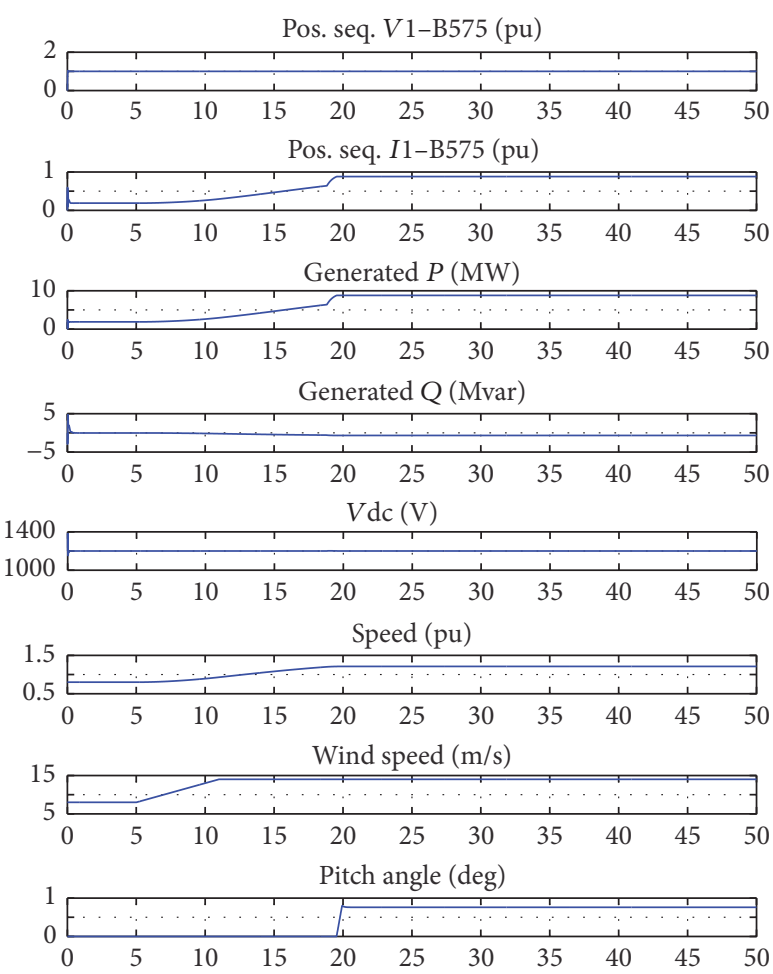

FIGURE 15: Simulation results for normal operation with step change increase in wind speed from $8 \mathrm{~m} / \mathrm{s}$ to $14 \mathrm{~m} / \mathrm{s}$ at 5 -second mark.

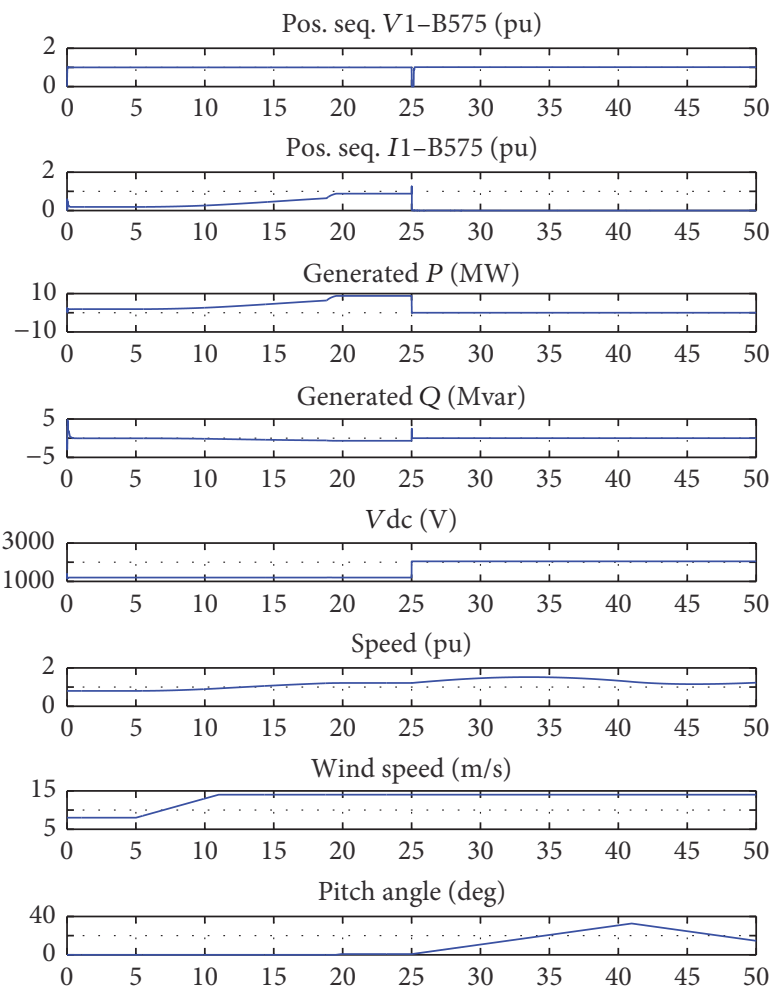

FIGURE 16: Simulation results for fault condition with a step change increase in wind speed from $8 \mathrm{~m} / \mathrm{s}$ to $14 \mathrm{~m} / \mathrm{s}$ at 5 -second mark followed by a $150 \mathrm{~ms}$ duration three phases to ground fault at 25 second mark. (iii) Good performance under both steady state and transient/fault states: this is in terms of accuracy of reference tracking, stability, and speed of response.

(iv) Reduced computation burden: this includes reduction or complete elimination of sequence decomposition and reference frame transformations. This reduces computing power and memory requirements and as such costs. It also reduces time delays and errors [97].

(v) Simplicity of implementation: the control system values such as resistor and gain values should be easily and quickly obtained. The system should also not introduce other problems that will require suppression or elimination.

Among the reviewed proposed control systems, the SMC strategy, especially in combination with FLC as proposed in [56], seems the most attractive choice as it best meets the qualities given above.

\section{Conclusion}

The DFIG WECS is presented from its construction, operation, advantages and shortcomings, modelling, control solutions, response to faults, and, finally, simulation. Different control approaches used to date have been explored with various control strategies being presented. Possible faults expected in the operation of the DFIG WECS and ways of tackling them have also been presented. Sample simulation results have been presented underlining the need for FRT capability. The paper has brought out issues to consider for an optimal control strategy which must integrate FRT capabilities so as to satisfy the ever stringent grid connection codes as well as taking into consideration the cost implications of its implementation.

\section{Conflicts of Interest}

The authors declare that there are no conflicts of interest regarding the publication of this paper.

\section{References}

[1] World Wind Energy Association, 2016, http://www.wwindea .org/wwea-half-year-report-worldwind-wind-capacity-reached456-gw.

[2] T. Ackerman, Wind Power in Power Systems, John Wiley and Sons Ltd, England, UK, 2005.

[3] K. E. Okedu and U. Roland, "Low voltage ride through methods for DFIG VSWT," Journal of Emerging Trends in Engineering and Applied Sciences, vol. 5, no. 8, pp. 221-226, 2014.

[4] D. A. Rivkin, L. D. Anderson, and L. Silk, Wind Turbine Control Systems, Jones and Bartlett Learning, Massachusetts, Mass, USA, 2013.

[5] Vestas Wind Systems A/S, 2014, https://www.vestas.com/ en/products/turbines.

[6] A. Bonanomi, "Powerful analysis of wind turbine gearboxes," Power Transmission World, 2014, http://www.powertransmissionworld.com/powerful-analysis-of-wind-turbine-gearboxes/. 
[7] F. Blaabjerg, M. Liserre, and K. Ma, "Power electronics converters for wind turbine systems," IEEE Transactions on Industry Applications, vol. 48, no. 2, pp. 708-719, 2012.

[8] J. Zhang, G. Chen, and X. Cai, "Thermal smooth control for Multi-MW parallel wind power converter," in Proceedings of the 2013 IEEE International Conference of IEEE Region 10, IEEE TENCON 2013, pp. 1-4, October 2013.

[9] T. Lei, M. Barnes, and A. C. Smith, "Thermal cycling evaluation for DFIG wind turbine power converter based on joint modelling," in Proceedings of the 5th Annual IEEE Energy Conversion Congress and Exhibition, ECCE 2013, pp. 3845-3851, usa, September 2013.

[10] Y. M. Alsmadi, L. Xu, F. Blaabjerg, A. P. Ortega, and A. Wang, "Comprehensive analysis of the dynamic behavior of gridconnected DFIG-based wind turbines under LVRT conditions," in Proceedings of the 7th Annual IEEE Energy Conversion Congress and Exposition, ECCE 2015, pp. 4178-4187, can, September 2015.

[11] S. Sharma, J. P. Mishra, and S. Datta, "Sliding mode power control of a DFIG based variable speed wind energy conversion system," in Proceedings of the 12th IEEE International Conference Electronics, Energy, Environment, Communication, Computer, Control, INDICON '15, December 2015.

[12] "Power quality basics: voltage sags or dips," Power Quality in Electrical Systems, 2011, http://www.powerqualityworld .com/2011/03/voltage-sags-dips-power-quality-basics.html.

[13] "Power quality basics: voltage swell," Power Quality in Electrical Systems, 2011, http://www.powerqualityworld.com/ 2011/04/voltage-swell-power-quality-basics.html.

[14] G. Abad, J. Lopez, M. Rodriguez, L. Marroyo, and G. Iwanski, Doubly Fed Induction Machine: Modelling and Control for Wind Energy Generation, John Wiley and Sons, New Jersey, NJ, USA, 2011.

[15] A. M. S. Yunus, M. A. S. Masoum, and A. Abu-Siada, "Application of SMES to enhance the dynamic performance of DFIG during voltage sag and swell," IEEE Transactions on Applied Superconductivity, vol. 22, no. 4, 2012.

[16] The MathWorks, Inc., MATLAB@ 1984-2010, http://www .mathworks.com.

[17] Gamesa Corporacion Tecnologica, S.A., 2014, http://www .gamesacorp.com/en/products-and-services/wind-turbines/.

[18] Siemens Wind Power GmbH, 2015, http://www.siemens.com/ global/en/home/markets/wind/turbines/technology/features.html.

[19] S. Heir, Grid Integration of Wind Energy Conversion Systems, John Wiley and Sons Ltd, England, UK, 2nd edition, 2006.

[20] M. Rahimi and M. Parniani, "Low voltage ride-through capability improvement of DFIG-based wind turbines under unbalanced voltage dips," International Journal of Electrical Power and Energy Systems, vol. 60, pp. 82-95, 2014.

[21] Ingeteam, "Power converter training manual," 2014, http://www ingeteam.com.

[22] D. Zhou, F. Blaabjerg, M. Lau, and M. Tonnes, “Thermal behavior optimization in multi-MW wind power converter by reactive power circulation," IEEE Transactions on Industry Applications, vol. 50, no. 1, pp. 433-440, 2014.

[23] H. L. Hansen, L. Helle, F. Blaabjerg, E. Ritchie, S. MunkNielsen, H. Bindner et al., Conceptual survey of generators and power electronics for wind turbines, RISO National Laboratory, Roskilde, Denmark, 2001.

[24] M. Boutoubat, L. Mokrani, and M. Machmoum, "Control of a wind energy conversion system equipped by a DFIG for active power generation and power quality improvement," Renewable Energy, vol. 50, pp. 378-386, 2013.

[25] A. Gupta, S. N. Singh, and D. K. Khatod, "Modeling and simulation of doubly fed induction generator coupled with wind turbine-An overview," Journal of Engineering, Computers \&amp; Applied Sciences, vol. 2, no. 8, 2013.

[26] K. E. Okedu, "Applications of wind power generation in grid connected power system," The Pacific Journal of Science and Technology, vol. 13, no. 2, 2012.

[27] T. Burton, N. Jenkins, D. Sharpe, and E. Bossanyi, Wind Energy Handbook, John Wiley and Sons Ltd, England, UK, 2nd edition, 2011.

[28] A. Petersson, Analysis, modeling and control of doubly-fed induction generators for wind turbines [Ph.D. thesis], Chalmers University of Technology, Göteborg, Sweden, 2005.

[29] K. E. Okedu, R. Takahashi, J. Tamura, and S. M. Muyeen, "Comparative study on current and voltage controlled voltage source converter based variable speed wind generator," in Proceedings of the 2011 2nd International Conference on Electric Power and Energy Conversion Systems, EPECS '11, November 2011.

[30] J. J. Justo, F. Mwasilu, and J.-W. Jung, "Doubly-fed induction generator based wind turbines: a comprehensive review of fault ride-through strategies," Renewable and Sustainable Energy Reviews, vol. 45, pp. 447-467, 2015.

[31] R. Teodorescu, M. Liserre, and P. Rodriquez, Grid Converters for Photovoltaic and Wind Power systems, John Wiley and Sons Ltd, England, UK, 2011.

[32] D. A. Rivkin, M. Randall, and L. Silk, Wind Power Generation and Distribution, Jones and Bartlett Learning, Massachusetts, Mass, USA, 2013.

[33] M. Ali, Wind Energy Systems Solutions for Power Quality and Stabilization, CRC Press, Boca Raton, Fla, USA, 2012.

[34] O. P. Mahela and A. G. Shaik, "Comprehensive overview of grid interfaced wind energy generation systems," Renewable and Sustainable Energy Reviews, vol. 57, pp. 260-281, 2016.

[35] R. Prasad, Low voltage ride-through capability for matrix converters fed adjustable-speed induction machine drives for industrial and wind appliances [Ph.D. thesis], University of Minnesota, 2011.

[36] M. A. Abdullah, A. H. M. Yatim, C. W. Tan, and R. Saidur, "A review of maximum power point tracking algorithms for wind energy systems," Renewable and Sustainable Energy Reviews, vol. 16, no. 5, pp. 3220-3227, 2012.

[37] N. Cherfia, D. Kerdoun, and A. Boumassata, "Sliding mode control indirect strategy of the active and reactive power for the wind turbine DFIG," in Proceedings of the Conference Internationale des Energies Renouvelables (CIER '13), Sousse, Tunisie, 2013.

[38] Z. Zheng, G. Yang, and H. Geng, "High voltage ride-through control strategy of grid-side converter for DFIG-based WECS," in Proceedings of the 39th Annual Conference of the IEEE Industrial Electronics Society (IECON '13), pp. 5282-5287, IEEE, Vienna, Austria, November 2013.

[39] C. Feltes, S. Engelhardt, J. Kretschmann, J. Fortmann, F. Koch, and I. Erlich, "High voltage ride-through of DFIG-based wind turbines," in Proceedings of the IEEE Power and Energy Society General Meeting-Conversion and Delivery of Electrical Energy in the 21st Century, pp. 1-8, IEEE, Pittsburgh, Pa, USA, July 2008.

[40] J. Morneau, A comparative evaluation of low voltage ride through solutions in wind turbines using doubly fed induction generators [M. S. thesis], McGill University, Montreal, Canada, 2008. 
[41] M. M. Baggu, Advanced control techniques for DFIG-based wind turbine converters to improve low voltage ride-through during system imbalances [Ph.D. thesis], Missouri University of Science and Technology, Missouri, Mo, USA, 2009.

[42] D. A. Rivkin, A. Liddell, and L. Silk, Wind Turbine Systems, Jones and Bartlett Learning, Massachusetts, Mass, USA, 2013.

[43] K. E. Okedu, S. M. Muyeen, R. Takahashi, and J. Tamura, "Comparative study of wind farm stabilization using variable speed generator and FACTS device," in Proceedings of the 2011 IEEE GCC Conference and Exhibition, GCC '11, pp. 569-572, February 2011.

[44] L. Shuhui and T. A. Haskew, "Analysis of decoupled d-q vector control in DFIG back-to-back PWM converter," in Proceedings of the 2007 IEEE Power Engineering Society General Meeting, pp. 1-7, June 2007.

[45] M. Mohseni, S. M. Islam, and M. A. S. Masoum, "Impacts of symmetrical and asymmetrical voltage sags on DFIG-based wind turbines considering phase-angle jump, voltage recovery, and sag parameters," IEEE Transactions on Power Electronics, vol. 26, no. 5, pp. 1587-1598, 2011.

[46] W. Qiao, G. K. Venayagamoorthy, and R. G. Harley, "Real-time implementation of a STATCOM on a wind farm equipped with doubly fed induction generators," IEEE Transactions on Industry Applications, vol. 45, no. 1, pp. 98-107, 2009.

[47] T. M. Masaud and P. K. Sen, "Modeling and control of doubly fed induction generator for wind power," in Proceedings of the 43rd North American Power Symposium, NAPS '11, 8, 1 pages, August 2011.

[48] J. Fletcher and J. Yang, "Introduction to the doubly-fed induction generator for wind power applications," in Paths to Sustainable Energy, A. Ng, Ed., InTech, 2010, http://www.intechopen.com/books/paths-to-sustainable-energy/introductionto-the-doubly-fed-inductiongenerator-for-wind-power-applications.

[49] S. Y. Rao and J. A. Laxmi, "Direct torque control of DFIG based wind turbine under voltage dips," International Journal of Advances in Engineering and Technology (IJAET), vol. 3, no. 2, pp. 711-720, 2012.

[50] Q. Liu, L. Yu, and G. Wu, "Comparison of control strategy for double-fed induction generator (DFIG)," in Proceedings of the 3rd International Conference on Measuring Technology and Mechatronics Automation, ICMTMA'11, pp. 741-744, January 2011.

[51] B. Rückert and W. Hofmann, "Commutation strategy for minimized common mode voltage using direct power control," in Proceedings of the 27th Annual IEEE Applied Power Electronics Conference and Exposition, APEC '12, pp. 106-112, February 2012.

[52] M. E. Zarei and B. Asaei, "A simple predictive direct current control for grid side converter of DFIG under ideal and nonideal supply voltage," in Proceedings of the 2013 13th International Conference on Environment and Electrical Engineering, EEEIC '13, pp. 278-283, November 2013.

[53] N. H. Saad, A. A. Sattar, and A. E.-A. M. Mansour, "Low voltage ride through of doubly-fed induction generator connected to the grid using sliding mode control strategy," Renewable Energy, vol. 80, pp. 583-594, 2015.

[54] A. M. Kassem, K. M. Hasaneen, and A. M. Yousef, "Dynamic modeling and robust power control of DFIG driven by wind turbine at infinite grid," International Journal of Electrical Power and Energy Systems, vol. 44, no. 1, pp. 375-382, 2013.
[55] Y. Wang, D. Zhao, B. Zhao, and H. Xu, "A new type of control strategy of DFIG in wind power system based on SMC," in Proceedings of the 11th International Conference on Electrical Machines and Systems, ICEMS '08, pp. 2428-2431, October 2008.

[56] D. Kairous and R. Wamkeue, "DFIG-based fuzzy sliding-mode control of WECS with a flywheel energy storage," Electric Power Systems Research, vol. 93, pp. 16-23, 2012.

[57] K. Belgacem, A. Mezouar, and A. Massoum, "Sliding mode control of a doubly-fed induction generator for wind energy conversion," International Journal of Energy Engineering, vol. 3, no. 1, pp. 30-36, 2013.

[58] M. I. Martinez, G. Tapia, A. Susperregui, and H. Camblong, "Sliding-mode control for DFIG rotor- and grid-side converters under unbalanced and harmonically distorted grid voltage," IEEE Transactions on Energy Conversion, vol. 27, no. 2, pp. 328339, 2012.

[59] Y. Zou, Modeling, control and maximum power point tracking (MPPT) of doubly-fed induction generator (DFIG) wind power system [Ph.D. thesis], The University of Akron, Ohio, USA, 2012.

[60] S. Abdeddaim and A. Betka, "Optimal tracking and robust power control of the DFIG wind turbine," International Journal of Electrical Power and Energy Systems, vol. 49, no. 1, pp. 234242, 2013.

[61] D. Campos-Gaona, E. L. Moreno-Goytia, and O. Anaya-Lara, "Fault ride-through improvement of DFIG-WT by integrating a two-degrees-of-freedom internal model control," IEEE Transactions on Industrial Electronics, vol. 60, no. 3, pp. 1133-1145, 2013.

[62] J. P. A. Vieira, M. V. A. Nunes, and U. H. Bezerra, "Using genetic algorithm to obtain optimal controllers for the DFIG converters to enhance power system operational security," in Proceedings of the 2010 IREP Symposium - Bulk Power System Dynamics and Control-VIII, IREP '10, August 2010.

[63] M. T. Hagh, S. Roozbehani, F. Najaty, S. Ghaemi, Y. Tan, and K. M. Muttaqi, "Direct power control of DFIG based wind turbine based on wind speed estimation and particle swarm optimization," in Proceedings of the 25th Australasian Universities Power Engineering Conference, AUPEC '15, pp. 1-6, September 2015.

[64] J. Puigcorbe and A. De-Beaumont, "Wind turbine gearbox reliability: the impact of rotor support," 2010, http://www .renewableenergyworld.com/articles/print/volume-13/issue-3/ wind-power/wind-turbine-gearbox-reliability.html.

[65] A. M. Ragheb and M. Ragheb, Wind Turbine Gearbox Technologies, 2011, http://www.intechopen.com/books/fundamentaland-advancedtopics-in-wind-power.

[66] “Wind Power Engineering," http://www.windpowerengineering .com/design/mechanical/gearboxes/gears-gearboxes-101/.

[67] W. Qiao and R. G. Harley, "Improved control of DFIG wind turbines for operation with unbalanced network voltages," in Proceedings of the 2008 IEEE Industry Applications Society Annual Meeting, IAS '08, pp. 1-7, October 2008.

[68] S. Karimi, A. Gaillard, P. Poure, and S. Saadate, "FPGAbased real-time power converter failure diagnosis for wind energy conversion systems," IEEE Transactions on Industrial Electronics, vol. 55, no. 12, pp. 4299-4308, 2008.

[69] M. Shahbazi, M. R. Zolghadri, P. Poure, and S. Saadate, "Wind energy conversion system based on DFIG with open switch fault tolerant six-legs AC_DC_AC converter," in Proceedings of the 2013 IEEE International Conference on Industrial Technology, ICIT '13, pp. 1656-1661, February 2013. 
[70] A. F. Abdou, A. Abu-Siada, and H. R. Pota, "Application of STATCOM to improve the LVRT of DFIG during RSC firethrough fault," in Proceedings of the 2012 22nd Australasian Universities Power Engineering Conference: "Green Smart Grid Systems”, AUPEC '12, pp. 1-6, September 2012.

[71] E. Giraldo and A. Garces, "An adaptive control strategy for a wind energy conversion system based on PWM-CSC and PMSG," IEEE Transactions on Power Systems, vol. 29, no. 3, pp. 1446-1453, 2014.

[72] C. Liu, D. Xu, N. Zhu, F. Blaabjerg, and M. Chen, "DC-voltage fluctuation elimination through a DC-capacitor current control for DFIG converters under unbalanced grid voltage conditions," IEEE Transactions on Power Electronics, vol. 28, no. 7, pp. 32063218, 2013.

[73] A. M. S. Yunus, A. Abu-Siada, and M. A. S. Masoum, "Impact of DC-link fault on the dynamic performance of DFIG," in Proceedings of the 2012 IEEE Power and Energy Society General Meeting, PES '12, pp. 1-6, July 2012.

[74] S. Hu, X. Lin, Y. Kang, and X. Zou, "An improved low-voltage ride-through control strategy of doubly fed induction generator during grid faults," IEEE Transactions on Power Electronics, vol. 26, no. 12, pp. 3653-3665, 2011.

[75] D. Zhu, X. Zou, Y. Kang, L. Deng, and Q. Huang, "Inductancesimulating control for DFIG-based wind turbine to ridethrough grid faults," in Proceedings of the 31st Annual IEEE Applied Power Electronics Conference and Exposition, APEC '16, pp. 3521-3525, March 2016.

[76] K. E. Okedu, S. M. Muyeen, R. Takahashi, and J. Tamura, "Wind farms fault ride through using DFIG with new protection scheme," IEEE Transactions on Sustainable Energy, vol. 3, no. 2, pp. 242-254, 2012.

[77] D. Xiang, L. Ran, P. J. Tavner, and S. Yang, "Control of a doubly fed induction generator in a wind turbine during grid fault ridethrough," IEEE Transactions on Energy Conversion, vol. 21, no. 3, pp. 652-662, 2006.

[78] K.E. Okedu, Low Voltage Ride through Enhancement of Grid Connected Wind Farms: Augmentation of Variable Speed Wind Turbines Fault Ride through (FRT) Capability, LAP Lambert Academic Publishing, Saarbrücken, Germany, 2012.

[79] V. Akhmatov, "Variable-speed wind turbines with doubly-fed induction generators part IV: uninterrupted operation features at grid faults with converter control coordination," Wind Engineering, vol. 27, no. 6, pp. 519-529, 2003.

[80] V. Akhmatov, "Variable-speed wind turbines with doubly-fed induction generators part III: model with the back-to-back converters," Wind Engineering, vol. 27, no. 2, pp. 79-91, 2003.

[81] K. E. Okedu, S. M. Muyeen, R. Takahashi, and J. Tamura, "Application of SDBR with DFIG to augment wind farm fault ride through," in Proceedings of the 2011 International Conference on Electrical Machines and Systems, ICEMS '11, August 2011.

[82] K. E. Okedu, S. M. Muyeen, R. Takahashi, and J. Tamura, "Effectiveness of current-controlled voltage source converter excited doubly fed induction generator for wind farm stabilization," Electric Power Components and Systems, vol. 40, no. 5, pp. 556574, 2012.

[83] M. Nasiri, J. Milimonfared, and S. H. Fathi, "A review of lowvoltage ride-through enhancement methods for permanent magnet synchronous generator based wind turbines," Renewable and Sustainable Energy Reviews, vol. 47, pp. 399-415, 2015.

[84] C. Laxmi, K. S. Latha, and Himani, "Improving the low voltage ride through capability of wind generator system using crowbar and battery energy storage system," International Journal of Engineering Science Invention, vol. 1, no. 7, pp. 14-19, 2013.

[85] A. O. Ibrahim, T. H. Nguyen, D.-C. Lee, and S.-C. Kim, "A fault ride-through technique of DFIG wind turbine systems using dynamic voltage restorers," IEEE Transactions on Energy Conversion, vol. 26, no. 3, pp. 871-882, 2011.

[86] A. Moghadasi, A. Sarwat, and J. M. Guerrero, "A comprehensive review of low-voltage-ride-through methods for fixed-speed wind power generators," Renewable and Sustainable Energy Reviews, vol. 55, pp. 823-839, 2016.

[87] J. Yao, H. Li, Z. Chen et al., "Enhanced control of a DFIG-based wind-power generation system with series grid-side converter under unbalanced grid voltage conditions," IEEE Transactions on Power Electronics, vol. 28, no. 7, pp. 3167-3181, 2013.

[88] K. E. Okedu, "A Study of wind farm stabilization using DFIG or STATCOM considering grid requirements," Journal of Engineering Science and Technology Review, vol. 3, no. 1, pp. 200-209, 2010.

[89] A. J. Prabhakar, Application of STATCOM for improved dynamic performance of wind farms in a power grid [M. S. thesis], Missouri University of Science and Technology, Missouri, Mo, USA, 2008.

[90] K. R. Padiyar, FACTS Controllers in Power Transmission and Distribution, New Age International Publishers, New Delhi, India, 2007.

[91] M. A. Abomahdi and A. K. Bharadwaj, "Modeling and simulation of DFIG to grid connected wind power generation using MatLab," International Journal of Electrical Engineering \&amp; Technology (IJEET), pp. 29-40, 2015.

[92] S. O. Faried, I. Unal, D. Rai, and J. Mahseredjian, "Utilizing DFIG-based wind farms for damping subsynchronous resonance in nearby turbine-generators," IEEE Transactions on Power Systems, vol. 28, no. 1, pp. 452-459, 2013.

[93] C. Alvarez, H. Amarís, O. Samuelsson, D. Flórez, and L. González, "Custom power systems and software platforms for wind farms under voltage dips situations," in Proceedings of the 43rd International Universities Power Engineering Conference, UPEC '08, pp. 1-4, September 2008.

[94] M. Kayikci and J. Milanovic, "DFIG modelling and the relevance of model simplification," in Proceedings of the 18th International Conference and Exhibition on Electricity Distribution (CIRED '05), 2005.

[95] C. Hamon, K. Elkington, and M. Ghandhari, "Doubly-fed induction generator modeling and control in DigSilent PowerFactory," in Proceedings of the 2010 International Conference on Power System Technology: Technological Innovations Making Power Grid Smarter, POWERCON '10, October 2010.

[96] J. He, Q. Li, S. Qin, and R. Wang, "DFIG wind turbine modeling and validation for LVRT behavior," in Proceedings of the 2012 IEEE Innovative Smart Grid Technologies-Asia, ISGT Asia, pp. 1-5, May 2012.

[97] J. Kearney, M. F. Conlon, and E. Coyle, "The application of multi frequency resonant controllers in in a DFIG to improve performance by reducing unwanted power and torque pulsations and reducing current harmonics," in Proceedings of the 2010 45th International Universities' Power Engineering Conference, UPEC '10, September 2010. 


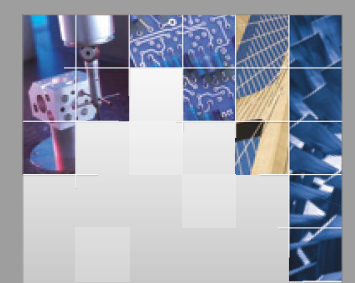

\section{Enfincering}
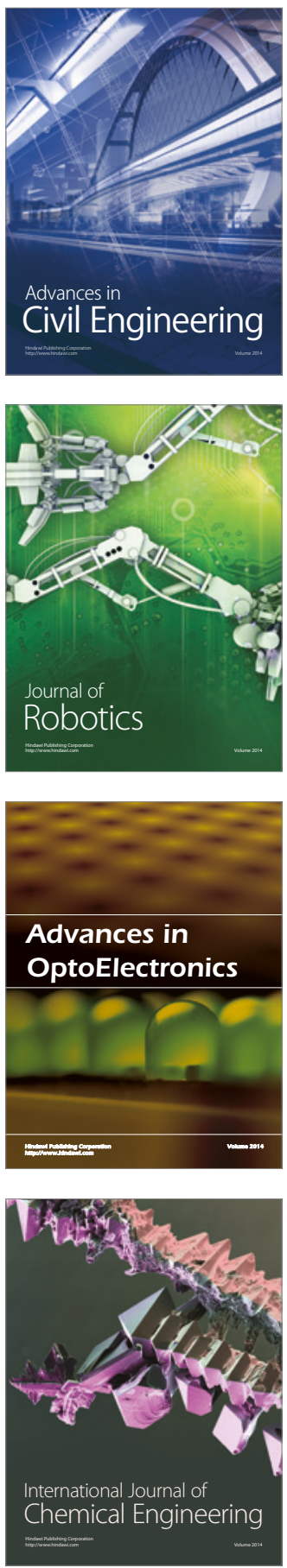

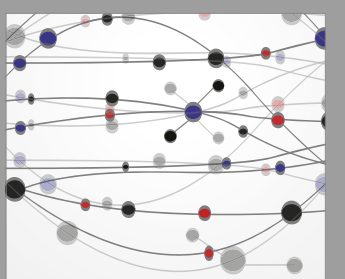

The Scientific World Journal

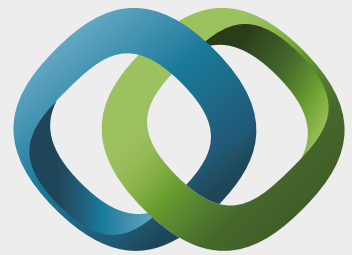

\section{Hindawi}

Submit your manuscripts at

https://www.hindawi.com
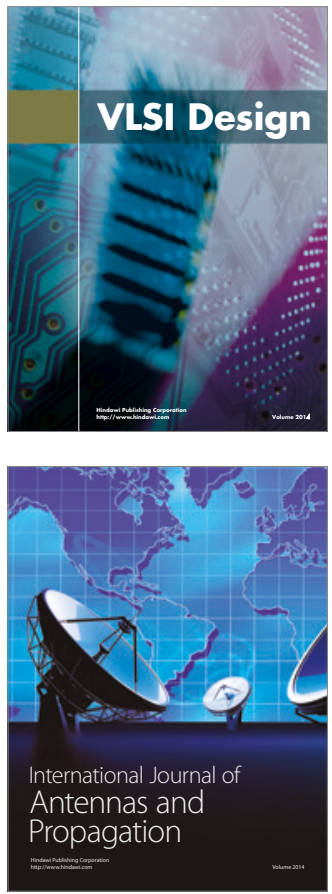

\section{Rotating}

Machinery
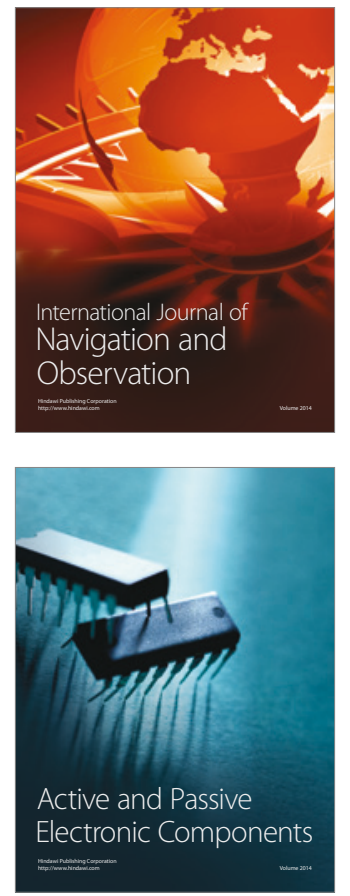
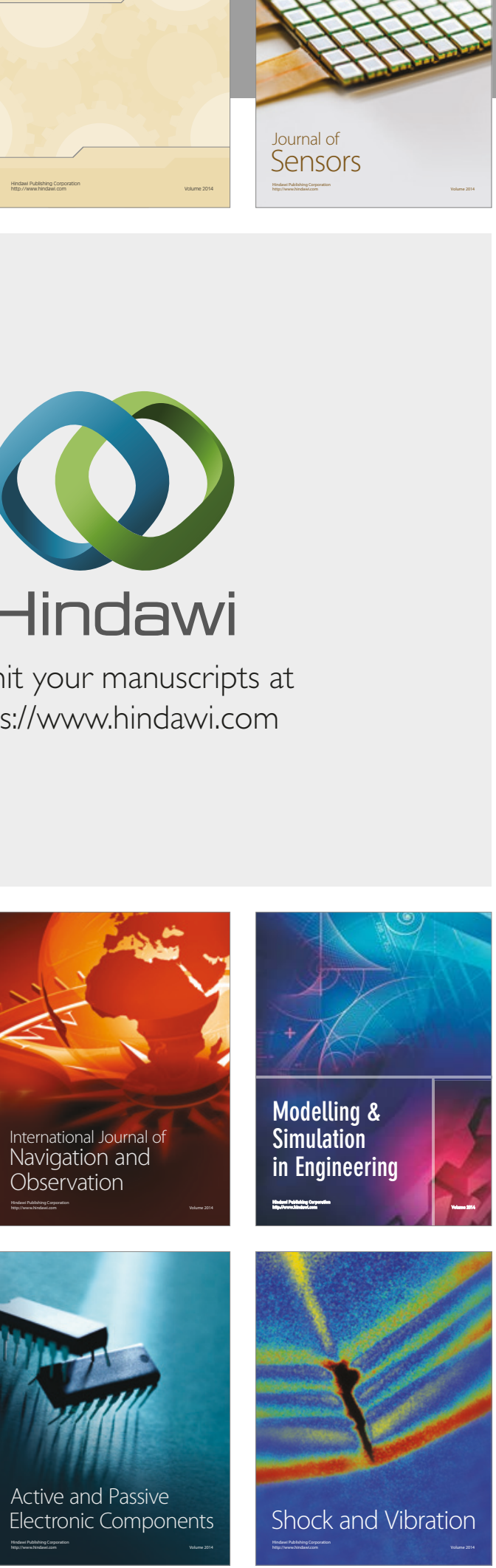
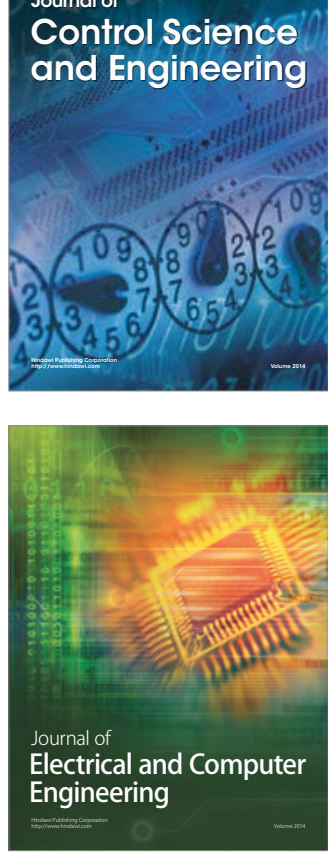

Distributed

Journal of

Control Science

and Engineering
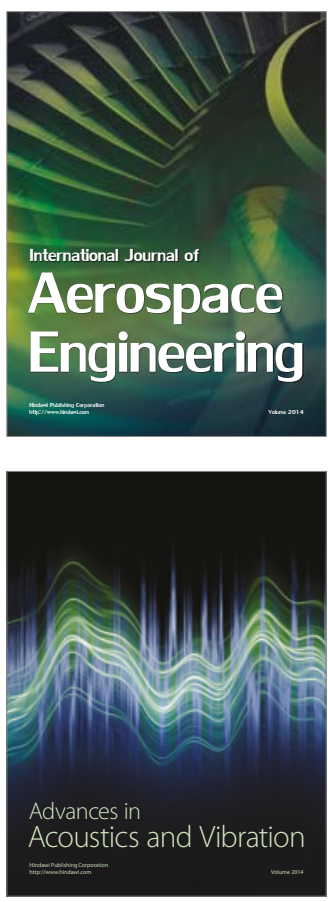

Sensor Networks 